\title{
10. NEOGENE AND QUATERNARY PLANKTONIC FORAMINIFERAL BIOSTRATIGRAPHY OF THE CANARY ISLAND REGION ${ }^{1}$
}

\author{
Rosanna Maniscalco ${ }^{2}$ and Charlotte A. Brunner ${ }^{3}$
}

\begin{abstract}
We examined planktonic foraminifers from Sites 953 and 954 in the Canary Island region. Site 953 is stratigraphically the best site with a complete Quaternary to middle Miocene sequence of pelagic and volcaniclastic sediments deposited in the sedimentary basin north of Gran Canaria. At Site 954, on the island flank, several distinct unconformities disrupt the sequence, complicating the biostratigraphy. We adopted the zonation of Berggren $(1973,1977)$ and Berggren et al. $(1983,1995 b)$ and recognized several of Berggren's zones, although some difficulties arose because of the absence of many zonal markers from the area and the diachronism of several species. Additionally, preservation is poor in the Miocene, hindering zonal assignment by reducing or eliminating the more solution-susceptible species.

We placed the Pliocene/Pleistocene boundary above the last occurrence of Globigerinoides obliquus extremus Bolli and Bermudez following the suggestion of Berggren et al. (1995b), because Globigerinoides fistulosus, whose last occurrence defines the base of Zone PT1, does not occur in our samples. We did not use the first occurrence of Globorotalia truncatulinoides (d'Orbigny) because it is diachronous in the Atlantic Ocean. We consider the highest occurrence of the planktonic foraminifer Globorotalia juanai Bermudez and Bolli a useful datum marker to define the Miocene/Pliocene boundary in the Canary Island region, where the last occurrence of Globoquadrina dehiscens (Chapman, Parr, and Collins), recorded within upper Chron C5n at Sites 953 and 954, and the first occurrence of Globorotalia tumida (Brady), which is rare and sporadic, are not useful for this purpose.
\end{abstract}

\section{INTRODUCTION}

The main purpose of this research was to define biostratigraphic zonal boundaries and events for the Canary Island area. Weaver and Clement (1986, 1987) and Weaver and Raymo (1989) set limits to the applicability of existing subtropical and temperate zonations in the north and equatorial Atlantic regions, where some zonal markers are very diachronous, whereas others are synchronous in their occurrence with latitude. Consequently, we tested the existing zonal schemes (Berggren, 1973, 1977; Berggren et al., 1983, 1995b) which, in the Canary Island region, suffer from the diachronism of several species (e.g., Globorotalia truncatulinoides, Globoquadrina dehiscens, Globigerina nepenthes, and Globorotalia margaritae) and the lack of many zonal markers (e.g., Globigerinoides fistulosus). Comparisons of identified datum events for the Canary Island region to published events (Berggren et al., 1985, 1995a, 1995b) show a different stratigraphic range for several species. Weaver and Raymo (1989) showed that sea-surface temperature could limit the geographic ranges of some of the tropical planktonic foraminifers, and this seems to be the case at Sites 953 and 954, which lie within the cool Canary Current.

Sites 953 and 954 of Leg 157 are located at a relatively shallow water depth, 3577.8 and $3485.2 \mathrm{~m}$, respectively. We compared preservation and abundance of planktonic foraminifers with variation of the calcium carbonate content downhole, attempting to relate varying amount of dissolution to effective changes of the calcium carbonate compensation depth (CCD).

\section{LITHOLOGY}

Sites 953 and 954 are located on the volcanic apron of Gran Canaria with Site 954 in the more proximal position relative to volcaniclastic input. Their sequences consist of pelagic nannofossil oozes with foraminifers interbedded with frequent turbidites and several debris flows and lapilli flows shed from Gran Canaria. The turbidites have two end-member types: (1) a carbonate type dominated by neritic shelly debris, including shallow-water benthic foraminifers and bryozoans, and (2) a volcaniclastic type dominated by pumice and crystals. The turbidite events are frequent, the percentage of sand units per core peaking in the latest Pleistocene, during the Pliocene Roque Nublo events, and the Miocene Fataga and Mogán events (Schmincke, Weaver, Firth, et al., 1995, p. 331). Several distinct unconformities disrupt the sequence at Site 954. Most notable is a Pliocene/Pleistocene hiatus associated with a lapilli flow and poor core recovery, which caused a disruption spanning $\sim 1.5$ m.y. Two other unconformities are associated with lapilli and debris flows, and two disconformities occur within pelagic units with no obvious depositional event in association. By contrast, the pelagic units at both sites show remarkably little influence from shallow-water sources, based on the rare occurrences of benthic foraminifers and intermixed volcaniclastic debris. The lack of disturbance to pelagic units combined with apparent minimal erosion caused by depositional events may account for the relatively continuous biostratigraphic record recovered from Site 953.

\section{MATERIALS AND METHODS}

We sampled preferentially from pelagic oozes, but in the lower part of the sequence at both sites we took several samples from turbiditic muds, dark volcanic sands, and calcareous sands. One sample in every other section to one sample per section was taken.

Unlithified samples were washed through a $63-\mu \mathrm{m}$ sieve with tap water and dried quickly under heat lamps. Lithified samples were
${ }^{1}$ Weaver, P.P.E., Schmincke, H.-U., Firth, J.V., and Duffield, W. (Eds.), 1998. Proc. ODP, Sci. Results, 157: College Station, TX (Ocean Drilling Program).

${ }^{2}$ Istituto di Geologia e Geofisica, Università di Catania, Corso Italia 55, 95129 Catania, Italy.maniscal@mbox.umict.it

${ }^{3}$ Institute of Marine Sciences, University of Southern Mississippi, John C. Stennis Space Center, MS 39529, U.S.A. 
broken into small pieces with a hammer, washed on a stack of sieves with $1-\mathrm{mm}$ and $63-\mu \mathrm{m}$ openings, dried under heat lamps, boiled in a $1 \%$ (by weight) Calgon solution, and rewashed on a $63-\mu \mathrm{m}$ screen. Further details have been already described (Shipboard Scientific Party, 1995a). In this paper, we switched from the composite time scale used during Leg 157 (Shipboard Scientific Party, 1995a) to that used in Berggren et al. (1995a, 1995b).

\section{ABUNDANCE PRESERVATION OF FORAMINIFERS AND CALCIUM CARBONATE CONTENT}

At Site 953, in pelagic oozes, preservation was good and abundance was moderate to high for planktonic foraminifers to $\sim 300$ meters below seafloor (mbsf). Below this depth, close to the Miocene/Pliocene boundary, abundance and preservation gradually decreased. Preservation deteriorated markedly below $\sim 555.9$ mbsf, making zonal assignments difficult. At Site 954, planktonic foraminifers are generally abundant to the base of the Pliocene at $255 \mathrm{mbsf}$ and are few to common in abundance to the top of the basal basalt breccia (408 mbsf). They are poorly preserved below $\sim 280 \mathrm{mbsf}$, except in the basalt breccia, where they are well preserved in the lithified matrix. Preservation of calcareous microfossils reflects the pattern of calcium carbonate content of the sediments. Figure 3 (from Schmincke, Weaver, Firth, et al., 1995, p. 332) shows that the calcium carbonate content of pelagic sediments has remained relatively uniform ( $56 \%)$ to $400 \mathrm{mbsf}$, but below this depth samples decrease in $\mathrm{CaCO}_{3}$. A similar trend is observed at Site 954 (fig. 5 from Schmincke, Weaver, Firth, et al., 1995, p. 403), where in the upper part of the section to $300 \mathrm{mbsf}$, the calcium carbonate content is $\sim 65 \%$ (slightly higher than at Site 953 ), but becomes less and more variable (between $35 \%$ and $75 \%$ ) in the lower part of the section in the interval between 300 and 410 mbsf. Site 954 is located on the outermost edge of the flank of Gran Canaria, 93 m shallower than Site 953, and it is likely it had a higher elevation also during Miocene times accounting for the slightly larger amount of calcium carbonate.

\section{RESULTS The Pleistocene}

The well-preserved Pleistocene assemblages at Sites 953 and 954 are a mixture of cool subtropical and temperate faunas, and are dominated by dextral Neogloboquadrina pachyderma (Ehrenberg), Globorotalia inflata (d'Orbigny), Globigerinoides ruber (d'Orbigny) white form, Globigerinita glutinata (Egger), Globigerina cf. Globigerina bulloides, Globigerinella aequilateralis (Brady), Globigerina bulloides d'Orbigny, Globigerina falconensis Blow, dextral Globorotalia truncatulinoides, and Orbulina universa d'Orbigny. The fauna is similar to those from the vicinity of Azores Islands (Corliss, 1975; Weaver, 1987), the African continental margin of Western Sahara (Site 369; Pflaumann and Krasheninnikov, 1979), and the northern Cape Verde Islands (Sites 657 and 659; Weaver and Raymo, 1989). These areas lie within the cool North Atlantic and Canary Currents, which form the north and west limbs of the North Atlantic gyre and which share similar water masses (Sverdrup et al., 1947). At Site 953, the relative proportions of species in the lower Pleistocene assemblage differ distinctly from those of the upper Pleistocene assemblage (below $72.92 \mathrm{mbsf}$ near the last occurrence (LO) of large Gephyrocapsa $>5.5 \mu \mathrm{m}$; Sblendorio-Levy and Howe, Chap. 8, this volume). The lower Pleistocene assemblage has fewer and sporadic G. truncatulinoides, fewer N. pachyderma and G. inflata, and more G. glutinata and G. ruber. A short interval of relatively high frequencies of Neogloboquadrina dutertrei (d'Orbigny) embraces the Pliocene/Pleistocene boundary, a pattern observed in the central
North Atlantic Ocean (Weaver, 1987). At Site 954, the equivalent lower Pleistocene sequence is entirely missing because of the poor core recovery of a thick lapillistone between 79.2 and 109.7 mbsf.

We adapted the Pleistocene zonation of Berggren et al. (1995a, 1995b) to the Canary Island region (Figs. 1, 2). Zone PT1 is defined as the interval containing $G$. truncatulinoides between the present day and the extinction of Globigerinoides obliquus extremus. We used G. obliquus extremus in substitution for G. fistulosus (Schubert) at Berggren et al.'s (1995b) suggestion, because we did not observe G. fistulosus in the Canary Island region. We followed the taxonomic criteria of Bolli and Saunders (1985) for recognition of G. obliquus extremus. The Pleistocene sequences at the two sites range from the surface to Samples 157-953A-14H-3, 134-136 cm (125.94 mbsf), and $157-954 \mathrm{~A}-11 \mathrm{X}-1,0-2 \mathrm{~cm}$ (79.21 mbsf). We divided the Pleistocene into two parts, Subzones PT1b and PT1a (Table 1, backpocket foldout, this volume, Table 2). The partial range Subzone PT1b is defined as the interval characterized by the partial range of G. truncatulinoides following the extinction of Globorotalia tosaensis Takayanagi and Saito, which occurs in the early Brunhes Chron (Berggren et al., 1995a). The zone ranges from the surface to Samples 157-953A-4H-CC, 0-2 cm, and 157-954A-6H-2, 47-49 cm (36.09 and 40.97 mbsf, respectively), both of which fall between the highest stratigraphic occurrence of Pseudoemiliania lacunosa and the base of the Brunhes Chron at Sites 953 and 954 (B. Herr and M. Fuller, pers. comm., 1996; Sblendorio-Levy and Howe, Chap. 8, this volume). The interval Subzone PT1a is defined as the interval between the extinction of G. obliquus extremus and the extinction of G. tosaensis, and is recognized at both sites. We explored the utility of Ericson and Wollin's (1968) zonation in the region, but found it unusable because the Globorotalia menardii plexus is so exceedingly rare and sporadic that zonal boundaries cannot be placed with any certainty.

Several other important biostratigraphic events characterize the Pleistocene sequences (Table 1, back-pocket foldout, this volume, Table 2). Globorotalia crassaformis Galloway and Wissler and its subspecies, although not abundant, are frequent and persistent elements of the fauna. The first occurrence (FO) of Globorotalia crassaformis hessi Bolli and Premoli Silva and the last occurrence of Globorotalia crassaformis viola Blow (101.41 and $104.48 \mathrm{mbsf}$, respectively, at Site 953 and 77.66 and $79.21 \mathrm{mbsf}$, respectively, at Site 954) occur immediately below the last occurrence of Calcidiscus macintyrei at Site 953 (Sblendorio-Levy and Howe, Chap. 8, this volume), as it does at Hole 154A in the Caribbean Sea (Bolli and Premoli Silva, 1973; Hay and Beaudry, 1973). These taxa are also used to zone sequences at Sites 366 and 368 near the Cape Verde Islands and the Sierra Leone Rise (Pflaumann and Krasheninnikov, 1979). The G. crassaformis hessi and G. crassaformis viola datum levels may be useful in other regions of the subtropical and tropical Atlantic Ocean.

True Globigerina calida calida with chambers measurably longer in the radial direction than in width (Parker, 1962) are exceedingly rare in the Canary Island region, although forms assignable to Globigerina calida praecalida Blow are persistent throughout the Pleistocene. This fact limits the stratigraphic reliability of this datum level in the region. We do use the FO of G. calida calida in one application. We suspect that the Holocene and latest Quaternary intervals at Site 953 were removed by a biogenic turbidite containing abundant bryozoans and neritic benthonic foraminifers. The interpretation is supported by the occurrence of G. calida calida, which is limited to the core top sample, (Sample 157-953-1H-1, 0-2 cm, $0.01 \mathrm{mbsf}$ ) at Site 953. In contrast, the taxon first occurs $11.2 \mathrm{mbsf}$ at Site 954 (Sample 157-954A-3H-1, 67-69 cm).

Two other events are worthy of report. The first occurrence of pink G. ruber occurs at 43.71 and 77.2 mbsf at Sites 953 and 954, respectively, the former at the Brunhes/Matuyama boundary (B. Herr and M. Fuller, pers. comm., 1996), and the latter $26 \mathrm{~m}$ below the boundary (Figs. 1,2). The pink form is quite rare and sporadic in the region. Globorotalia hirsuta (d'Orbigny) similar to variant 1 of Park- 
Site 953

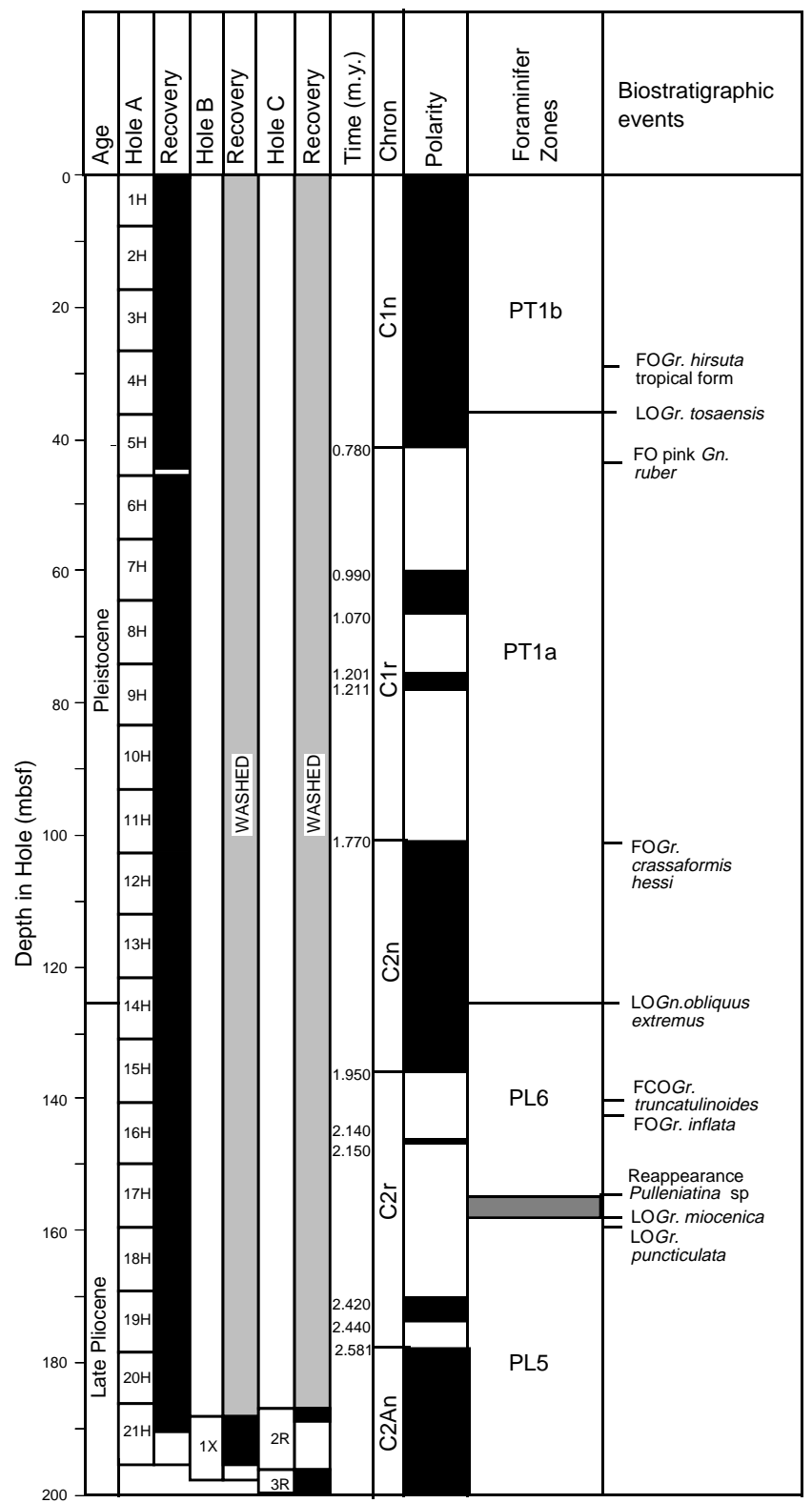

Site 953

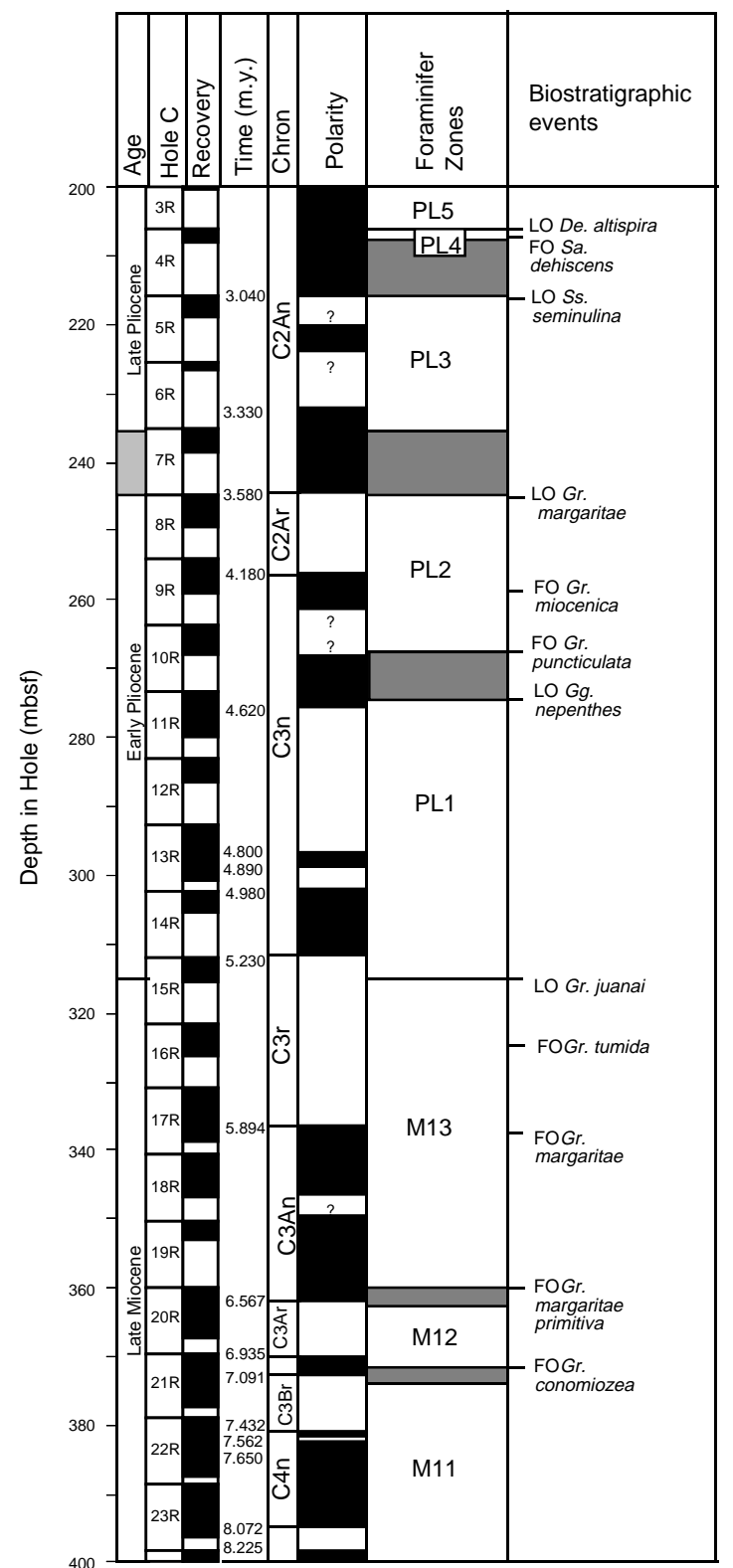

Figure 1. Magnetobiostratigraphy of Site 953 and selected planktonic foraminifers datum levels calibrated to Berggren et al. (1995a, 1995b) time scale. Paleomagnetic datums are from B. Herr and M. Fuller (pers. comm., 1996). The gray areas are intervals of poor biostratigraphic resolution because of lacking core recovery and/or absence of lithologies (hemipelagic marls and pelagic oozes) suitable for stratigraphic analysis. FO $=$ first occurrence, $\mathrm{LO}=$ last occurrence, and $\mathrm{FCO}=$ first common occurrence.

er (Parker, 1962; Parker, 1967; Blow, 1969) first occurs at 28.96 and $25.11 \mathrm{mbsf}$ in the middle Brunhes Chron (B. Herr and M. Fuller, pers. comm., 1996) at Sites 953 and 954, respectively, and other similar forms (variant 3 of Parker, 1962; G. crassula Cushman and Stewart in Parker, 1967; Globorotalia aff. hirsuta hirsuta in Iaccarino and Salvatorini, 1979) are found sporadically in the Quaternary and late Pliocene. Forms assigned to G. hirsuta also occur sporadically throughout Quaternary and late Pliocene sequences at sites near the West African Margin (Pflaumann and Krasheninnikov, 1979) and other regions of the world oceans, but the neotype described by Blow (1969), which appears equivalent to variant 1 of Parker (1962), occurs only in the latest Quaternary, first appearing in the middle Brunhes Chron (Berggren et al., 1995a) in the southwestern Atlantic
Ocean (Pujol and Duprat, 1983, with reference to variants 1 and 3 of Parker) and the central North Atlantic Ocean (Weaver, 1987).

Both sites contain many volcaniclastic and shallow-water, biogenic turbidites. In fact, the upper cores of Site 954, which is more proximal to Gran Canaria than is Site 953, are dominated by coarse biogenic turbidites (Cores 157-954-2H, 3H, and 5H), so the depthage relationships of datum levels above the base of the Brunhes Chron stand in question.

\section{The Pleistocene/Pliocene Boundary}

Based on planktonic foraminifers, the Pliocene/Pleistocene boundary is approximated by the last occurrence of $G$. obliquus extremus, 
Site 953

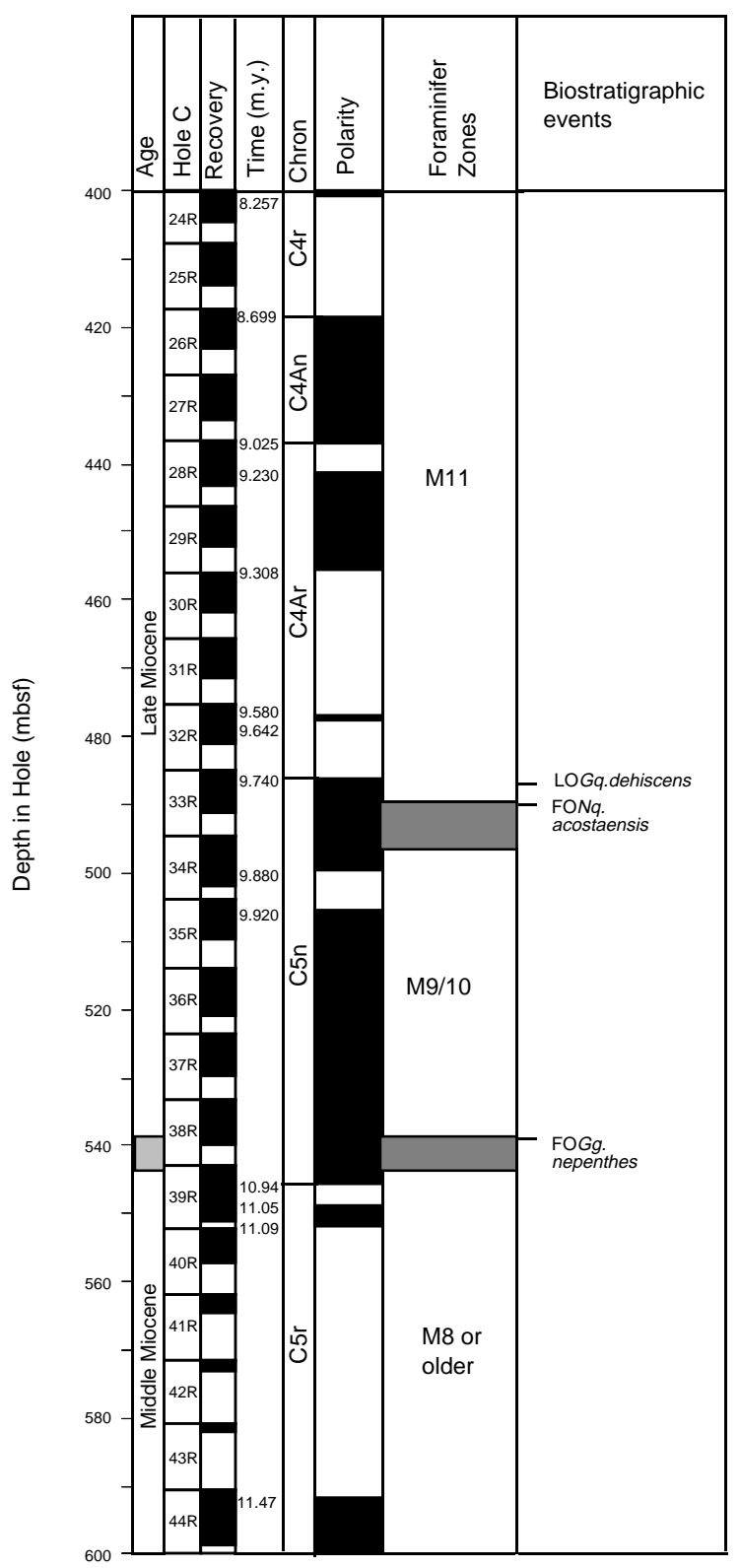

Figure 1 (continued).

which, at Site 953, lies in Sample 157-953A-14H-4, 103-105 cm (127.13 mbsf). The event falls within the lower third of the Olduvai Subchron ( $23 \mathrm{~m}$ below the top; B. Herr and M. Fuller, pers. comm., 1996) rather than at the top of the subchron, so the species regional last occurrence is older than its true extinction at $1.77 \mathrm{Ma}$ (Berggren et al., 1995a, 1995b; Chapman et al., 1996). The epoch boundary lies in the upper Olduvai at the type section in Vrica (Berggren et al., 1995, and references therein), so our approximation of the boundary is stratigraphically below its placement based on paleomagnetic stratigraphy (Fig. 1). At Site 954, the last occurrence of G. obliquus extremus, and, hence, the inferred epoch boundary falls within a disconformity and zone of poor recovery (Fig. 2).

\section{The Pliocene}

The well-preserved late Pliocene assemblage is dominated by $G$. glutinata, dextral N. pachyderma, Globigerina rubescens Hofker, G. ruber, Globigerina spp., Globigerina bulloides, Globorotalia puncticulata (Deshayes), dextral Neogloboquadrina acostaensis (Blow), $N$. dutertrei, and G. inflata. It is more diverse than the Pleistocene, and it has more G. rubescens, G. crassaformis, and Globigerinita glutinata and fewer dextral N. pachyderma, G. inflata, and G. ruber. Several species important to biostratigraphy are absent or rare in the Canary Island region. Among the tropical species, G. fistulosus and Pulleniatina finalis Banner and Blow are not observed, and Globorotalia pertenuis Beard is too sporadic to be useful for placing datum levels. Among the cool water species, G. crassula, and Globorotalia conomiozea Kennett are too sporadic to be useful in defining datum levels in the late Pliocene, and Neogloboquadrina atlantica is not observed.

The late Pliocene sequences at both Site 953 and 954 were successfully subdivided (Tables 1, 3, 4, back-pocket foldout, this volume) into Zones PL6 to PL3 of Berggren et al. (1995b). We were able to tie most datum levels to the excellent paleomagnetic stratigraphy at Site 954 (B. Herr and M. Fuller, pers. comm., 1996); however, we were unable to do this at Site 954 because the paleomagnetic events remain poorly resolved (Shipboard Scientific Party, 1995b).

The basal boundary of PL6 was placed above the last occurrence of Globorotalia miocenica Palmer, which lies below the Reunion Subchron (Berggren et al., 1995a) and is in good agreement with the same event observed at Ocean Drilling Program (ODP) Site 659 (Chapman et al., 1996). At Site 953, the last occurrence of G. miocenica (Fig. 1) is recorded in Sample 157-953-17H-6, 19-21 cm (157.79 mbsf), in the lower Matuyama Chron and below the Reunion Subchron (B. Herr and M. Fuller, pers. comm., 1996) as expected (Berggren et al., 1995a). The sequence at Site 954 is relatively complete, but a large unconformity caused by emplacement of a lapillistone removed all of Zone PL6, except one sample (Sample 157-954C-3R-CC, 0-2 cm; $100.10 \mathrm{mbsf}$ ) found in sediment within the lapillistone. Several useful datum levels occur within Zone PL6 at Site 953. The last occurrence of G. exilis Blow (Sample 157-953A$16 \mathrm{H}-3,116-118 \mathrm{~cm} ; 144.76 \mathrm{mbsf}$ ) is $1 \mathrm{~m}$ above the top of the Reunion Subchron, slightly higher than expected perhaps because of reworking (B. Herr and M. Fuller, pers. comm., 1996; Berggren et al., 1995a), and the reappearance of Pulleniatina (Sample 157-953A$17 \mathrm{H}-3,139-141 \mathrm{~cm} ; 154.49 \mathrm{mbsf}$ ) occurs below the Reunion Subchron as expected (Berggren et al., 1995a; B. Herr and M. Fuller, pers. comm., 1996).

The first appearance of $G$. truncatulinoides is much earlier than expected at Sites 953 and 954 and merits specific discussion. The species evolved in the Pacific Ocean near the Gauss/Matuyama boundary at $\sim 2.58 \mathrm{Ma}$, but it is generally held that it did not enter the Atlantic Ocean until 2 Ma within upper Zone PL6 (Dowsett, 1988; Berggren et al. 1995b; Chapman et al., 1996). This does not appear to be the case in the Canary Island region based on the Leg 157 sequences, in which sporadic invasions occurred in Zone PL5 well below the base of the Olduvai Subchron. At Site 953, the species briefly first appeared at $167.82 \mathrm{mbsf}$ in Zone PL5, $10 \mathrm{~m}$ above the Gauss/Matuyama boundary and $\sim 21 \mathrm{~m}$ below the base of the Reunion Subchron, then made a first common occurrence (FCO) at 140.56 mbsf just below the Olduvai Subchron (B. Herr and M. Fuller, pers. comm., 1996), where it is expected in the Atlantic Ocean (Dowsett, 1988; Berggren et al., 1995b; Chapman et al., 1996). At Site 954, G. truncatulinoides first appeared at 134.39 mbsf and recurred at 112.68 and $112.61 \mathrm{mbsf}$, all of which are in Zone PL5. The interval above this is disturbed by a lapilli flow that removed the upper part of PL5, most of PL6, and the lower Pleistocene. The puzzling occurrences in PL5 could have been because of downhole caving, but no other taxa from higher in the sequence were observed in the samples, although reworking of older material is evident. The early appearance of this species in Zone PL5 at Sites 953 and 954 requires confirmation at other Atlantic sites. We must point out that $G$. truncatulinoides was not reported in Zone PL5 at nearby Site 659 (Chapman et al., 1996).

Zones PL5, PL4, and PL3 are consistent with the zonal definitions of Berggren et al. (1995b). The base of Zone PL5 is marked by the last occurrence of Dentoglobigerina altispira (Cushman and Jarvis) 

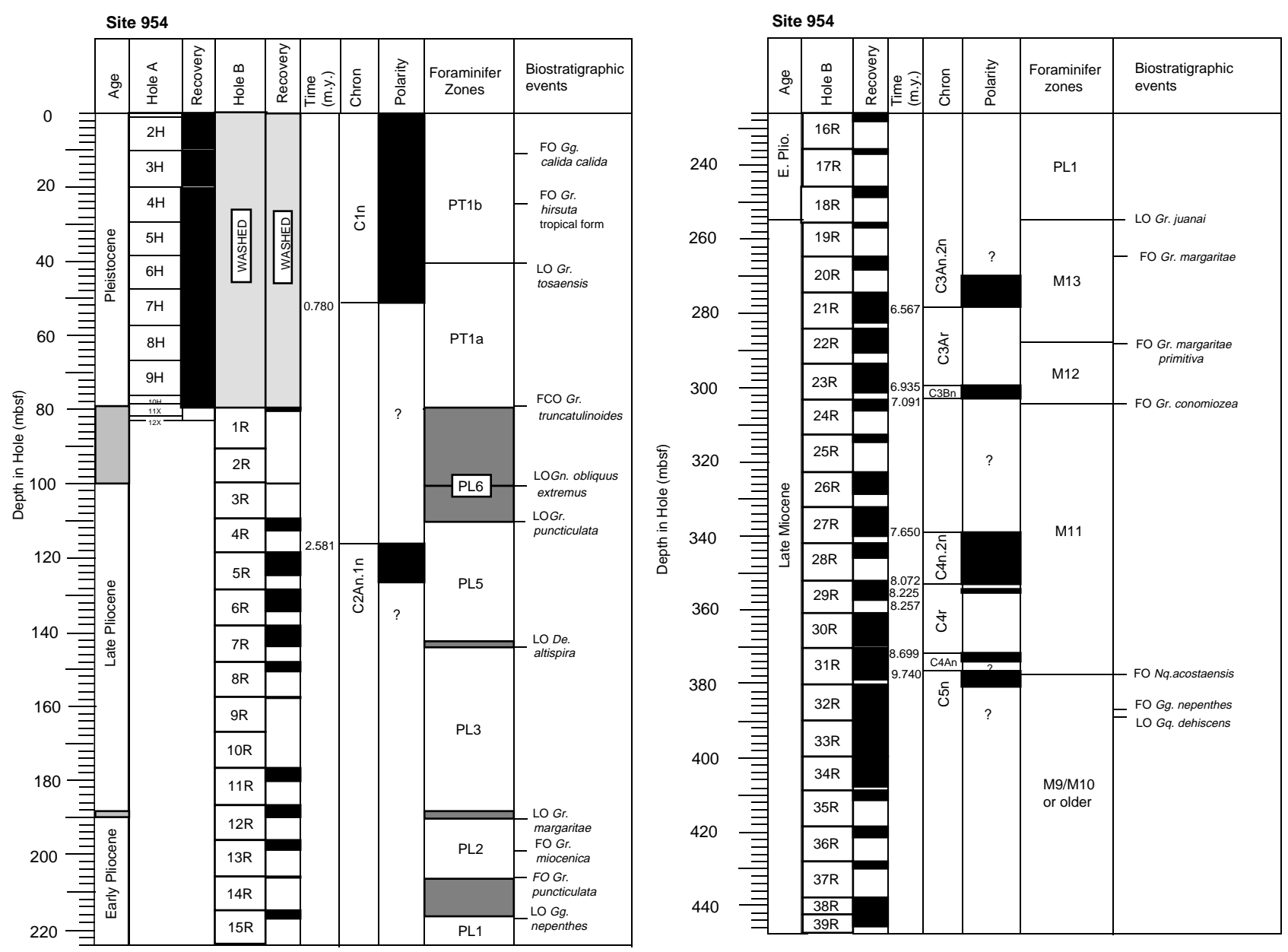

Figure 2. Magnetobiostratigraphy of Site 954 and selected planktonic foraminifers datum levels calibrated to Berggren et al. (1995a, 1995b) time scale. Paleomagnetic datums are from Shipboard Scientific Party (1995b). The gray areas are intervals of poor biostratigraphic resolution because of lacking core recovery and/or absence of lithologies (hemipelagic marls and pelagic oozes) suitable for stratigraphic analysis. $\mathrm{FO}=$ first occurrence, $\mathrm{LO}=$ last occurrence, and $\mathrm{FCO}=$ first common occurrence.

in Sample 157-953C-4R-1, 131-133 cm (207.41 mbsf), almost $9 \mathrm{~m}$ above the Kaena Subchron (B. Herr and M. Fuller, pers. comm., 1996), which is higher than expected (Berggren et al., 1995a), perhaps because of reworking evident in overlying samples at 198.57 and $184.80 \mathrm{mbsf}$ (Table 3, back-pocket foldout, this volume). At Site 954 (Fig. 2), the base of PL5 lies above Sample 157-954B-7R-4, 47$48 \mathrm{~cm}$ (143.57 mbsf), below the top of the Gauss (Shipboard Scientific Party, 1995b). We observed one useful datum level within PL5. G. puncticulata last appeared at Sample 157-953A-17H-CC, 0-2 cm (159.61 mbsf) in the early Matuyama Chron as expected (B. Herr and M. Fuller, pers. comm., 1996; Berggren et al., 1995a; Chapman et al., 1996). Although we found typical Globorotalia pertenuis, it was too rare and sporadic to place its last appearance with confidence, and we noted occurrences, apparently caused by reworking, above the top of the Gauss (B. Herr and M. Fuller, pers. comm., 1996; Berggren et al., 1995a). Zone PL5 is relatively complete at Site 953, although small disconformities may occur at major depositional events, like debris flows or lapilli deposits, and the zone suffers from some reworking of older material. In contrast, the top of this zone was lost at Site 954 during emplacement of the large lapillistone, as evidenced by the simultaneous disappearances of G. puncticulata, G. miocenica, and $G$. exilis at the top of the zone.

The base of Zone PL4 is marked by the last occurrence of Sphaeroidinellopsis seminulina (Schwager), which should occur in the base of the Kaena (Berggren et al., 1995a). However, the base of the Kaena and the top of the Mammoth are not recognized at Site 953
(Fig. 1), and the Kaena is not recognized at all at Site 954 (B. Herr and M. Fuller, pers. comm., 1996; Shipboard Scientific Party, 1995b). The highest stratigraphic occurrences of $S$. seminulina are found in Samples 157-953C-5R-1, 48-50 cm (216.28 mbsf), and 157-954B-7R-4, 47-48 cm (143.57 mbsf). PL4 is a brief zone of $\sim 30$ k.y., represented by only two samples at Site 953 and none at Site 954.

The basal boundary of Zone PL3 is marked by the last occurrence of G. margaritae Bolli and Bermudez between 236.25 and 245.11 mbsf at Site 953 and between 188.09 and 190.18 mbsf at Site 954 . The event occurs, as expected, at the Gauss/Gilbert boundary, which lies between 244.80 and $244.90 \mathrm{mbsf}$ at Site 953 , but is not recognized at Site 954 (Berggren et al., 1995a; B. Herr and M. Fuller, pers. comm., 1996; Shipboard Scientific Party, 1995b).

The basal boundary of Zone PL2 (Tables 3, 4, back-pocket foldout, this volume) is placed in Samples 157-953C-10R-CC, 0-2 cm (267.7 mbsf), and 157-954B-14R-CC, 0-2 cm (206.2 mbsf), above the LO of G. nepenthes Todd following Berggren et al. (1995b). At Site 953, the highest occurrence of $G$. nepenthes is close to the bottom of the Nunivak subchron (Fig. 1), whereas Berggren et al. (1985, 1995a) place it at the top of the Cochiti subchron. The LO of G. nepenthes at Site 954 (Fig. 2) falls within an interval with no reliable paleomagnetic record (Shipboard Scientific Party, 1995b). Our findings are consistent with Weaver and Raymo (1989), who show that $G$. nepenthes has an earlier LO at all sites affected by the Canary or Benguela currents. The evolutionary trend of Globorotalia margari- 


\begin{tabular}{|c|c|c|c|c|c|c|c|c|c|c|c|c|c|c|c|c|c|c|c|c|c|c|c|}
\hline Zone & 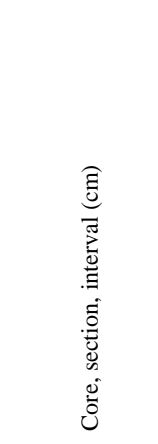 & 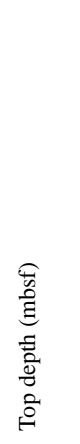 & 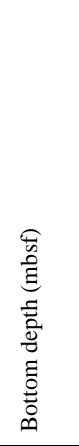 & Lithology & 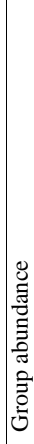 & 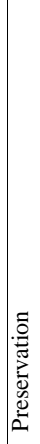 & \begin{tabular}{|l} 
\\
\\
\end{tabular} & 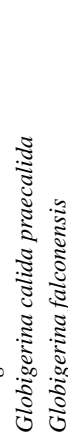 & & & & & & 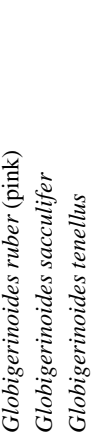 & & & 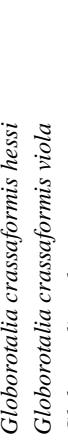 & & 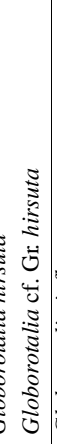 & 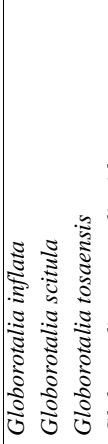 & 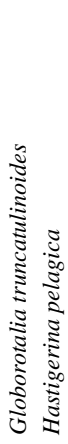 & 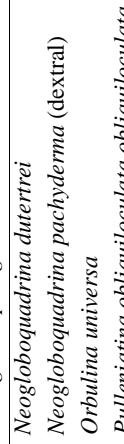 & 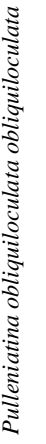 \\
\hline PT1b & $\begin{array}{l}1 \mathrm{H}-1,0-1 \\
1 \mathrm{H}-1,9-11 \\
1 \mathrm{H}-1,65-67 \\
1 \mathrm{H}-\mathrm{CC}, 0-2 \\
2 \mathrm{H}-1,2-4 \\
2 \mathrm{H}-1,52-54 \\
2 \mathrm{H}-\mathrm{CC}, 0-2 \\
3 \mathrm{H}-1,67-69 \\
3 \mathrm{H}-2,10-12 \\
3 \mathrm{H}-2,61-63 \\
3 \mathrm{H}-\mathrm{CC}, 0-2 \\
4 \mathrm{H}-3,51-53 \\
4 \mathrm{H}-4,60-62 \\
4 \mathrm{H}-\mathrm{CC}, 0-2 \\
5 \mathrm{H}-1,23-25 \\
5 \mathrm{H}-2,83-85 \\
5 \mathrm{H}-4,16-18 \\
5 \mathrm{H}-\mathrm{CC}, 0-2 \\
6 \mathrm{H}-2,47-49\end{array}$ & $\begin{array}{l}0 \\
0.09 \\
0.65 \\
0.85 \\
1.02 \\
1.52 \\
9.65 \\
11.2 \\
12.1 \\
12.6 \\
19.49 \\
23.5 \\
25.1 \\
29.26 \\
29.7 \\
31.8 \\
34.15 \\
38.93 \\
40.96 \\
\end{array}$ & $\begin{array}{r}0.02 \\
0.11 \\
0.67 \\
0.87 \\
1.04 \\
1.54 \\
9.67 \\
11.22 \\
12.12 \\
12.62 \\
19.51 \\
23.52 \\
25.12 \\
29.28 \\
29.72 \\
31.82 \\
34.17 \\
38.95 \\
40.98 \\
\end{array}$ & $\begin{array}{l}\text { Brown ooze } \\
\text { Brown ooze } \\
\text { Turbidite mud } \\
\text { Brown ooze } \\
\text { Brown ooze } \\
\text { Brown ooze } \\
\text { Black ash } \\
\text { Pelagic ooze } \\
\text { Pelagic ooze } \\
\text { Calcareous sand } \\
\text { Pumice pebble sand } \\
\text { Brown ooze } \\
\text { Brown ooze } \\
\text { Pelagic ooze } \\
\text { Pelagic ooze } \\
\text { Pelagic ooze } \\
\text { Pelagic ooze } \\
\text { Calcareous sand } \\
\text { Pelagic ooze }\end{array}$ & $\begin{array}{l}\text { A } \\
\text { A } \\
\text { A } \\
\text { A } \\
\text { A } \\
\text { A } \\
\text { F } \\
\text { A } \\
\text { A } \\
\text { A } \\
\text { A } \\
\text { A } \\
\text { A } \\
\text { A } \\
\text { A } \\
\text { A } \\
\text { A } \\
\text { F } \\
\text { A }\end{array}$ & $\begin{array}{l}G \\
G \\
G \\
G \\
G \\
G \\
G \\
P \\
M \\
M \\
G \\
M \\
M \\
M \\
M \\
G \\
M \\
M \\
G \\
G \\
M \\
G\end{array}$ & $\begin{array}{ll}\mathrm{C} & \mathrm{F} \\
\mathrm{F} & \mathrm{R} \\
\mathrm{R} & \mathrm{R} \\
\mathrm{F} & \mathrm{R} \\
\mathrm{C} & \mathrm{R} \\
\mathrm{C} & \mathrm{R} \\
\mathrm{C} & \mathrm{R} \\
\mathrm{C} & \\
\mathrm{C} \\
\mathrm{F} \\
\mathrm{R} \\
\mathrm{C} \\
\mathrm{R} \\
\mathrm{C} \\
\mathrm{C} \\
\mathrm{F} \\
\mathrm{C}\end{array}$ & $\begin{array}{ll}\mathrm{C} & \mathrm{C} \\
\mathrm{R} & \mathrm{C} \\
\mathrm{R} & \mathrm{C} \\
\mathrm{C} & \mathrm{F} \\
\mathrm{R} & \mathrm{F} \\
\mathrm{C} & \mathrm{C} \\
\mathrm{R} & \\
\mathrm{C} & \mathrm{F} \\
\mathrm{C} & \mathrm{C} \\
\mathrm{C} & \mathrm{C} \\
\mathrm{R} & \mathrm{R} \\
\mathrm{R} & \mathrm{F} \\
\mathrm{C} & \mathrm{F} \\
\mathrm{F} & \mathrm{R} \\
\mathrm{C} & \mathrm{C} \\
\mathrm{R} & \mathrm{C} \\
\mathrm{F} & \\
\mathrm{R} & \\
\mathrm{C} & \mathrm{C}\end{array}$ & $\begin{array}{ll}\mathrm{C} & \mathrm{F} \\
\mathrm{C} & \\
\mathrm{C} & \mathrm{F} \\
\mathrm{F} & \mathrm{R} \\
\mathrm{F} & \mathrm{C} \\
\mathrm{C} & \mathrm{R} \\
\mathrm{F} & \mathrm{F} \\
\mathrm{C} & \mathrm{F} \\
\mathrm{C} & \mathrm{R} \\
\mathrm{R} & \mathrm{F} \\
\mathrm{F} & \mathrm{R} \\
\mathrm{F} & \\
\mathrm{R} & \\
\mathrm{C} & \\
\mathrm{C} & \\
& \mathrm{C} \\
\mathrm{C} & \mathrm{R} \\
\end{array}$ & $\begin{array}{l}\mathrm{F} \\
\mathrm{F} \\
\\
\mathrm{F} \\
\mathrm{F} \\
\mathrm{R} \\
\mathrm{R}\end{array}$ & $\begin{array}{ll}\mathrm{C} & A \\
\mathrm{C} & \mathrm{C} \\
\mathrm{C} & \mathrm{A} \\
\mathrm{F} & \\
\mathrm{F} & - \\
\mathrm{F} & A \\
\mathrm{~F} & \mathrm{C} \\
\mathrm{C} & \mathrm{C} \\
\mathrm{C} & \mathrm{C} \\
\mathrm{C} & \mathrm{I} \\
\end{array}$ & $\begin{array}{ll}\text { C } & F \\
\text { C } & \text { R } \\
\text { C } & \\
\text { C } \\
\text { C } \\
\text { A } \\
\\
\text { A } \\
\text { A } \\
\text { A } & \text { R } \\
& \\
\text { A } \\
\text { A } \\
\text { A } \\
\text { A } \\
\text { A } \\
\text { C } & \text { F } \\
& \text { R } \\
\text { F } & \text { R } \\
\end{array}$ & $\begin{array}{l}\mathrm{C} \\
\mathrm{C} \\
\mathrm{C} \\
\mathrm{C} \\
\mathrm{F} \\
\mathrm{C} \\
\mathrm{C} \\
\mathrm{C} \\
\mathrm{C} \\
\mathrm{C} \\
\mathrm{C}\end{array}$ & $\begin{array}{lll}\mathrm{F} & \mathrm{F} & \mathrm{C} \\
\mathrm{R} & \mathrm{C} & \mathrm{C} \\
& \mathrm{R} & \\
\mathrm{R} & & \\
\mathrm{R} & & \mathrm{F} \\
& & \mathrm{F} \\
& & \mathrm{F} \\
& \mathrm{F} & \mathrm{F} \\
\mathrm{R} & & \mathrm{F} \\
\mathrm{R} & & \mathrm{F} \\
& \mathrm{R} & \\
\mathrm{R} & \mathrm{R} & \mathrm{F} \\
\mathrm{R} & \mathrm{R} & \mathrm{F} \\
& & \mathrm{R} \\
& \mathrm{F} & \mathrm{R} \\
\mathrm{R} & \mathrm{R} & \mathrm{F} \\
\mathrm{R} & \mathrm{F} & \\
\mathrm{R} & \mathrm{R} & \mathrm{F} \\
\end{array}$ & $\begin{array}{ll}C & C \\
C & \\
\text { F } & \\
F & \\
F & \\
F & \\
F & \\
F & \\
F & \\
F & R \\
\text { F } & R \\
R & F \\
F & R \\
F & F \\
F & F \\
\end{array}$ & $\begin{array}{l}\mathrm{F} \\
\mathrm{F} \\
\mathrm{R} \\
\mathrm{C} \\
\mathrm{F} \\
\\
\mathrm{R} \\
\mathrm{R} \\
\mathrm{F}\end{array}$ & $\begin{array}{l}\mathrm{R} \\
\mathrm{R}\end{array}$ & $\begin{array}{ll}\mathrm{R} & \mathrm{R} \\
& \mathrm{R} \\
& \mathrm{R} \\
& \mathrm{R} \\
\mathrm{R} & \mathrm{C} \\
\mathrm{R} & \mathrm{R} \\
\mathrm{F} & \mathrm{R} \\
\mathrm{F} & \mathrm{F}\end{array}$ & $\begin{array}{ll}\mathrm{F} & \mathrm{R} \\
\mathrm{R} & \mathrm{R} \\
\mathrm{R} & \mathrm{R} \\
\mathrm{R} & \mathrm{R} \\
\mathrm{R} & \mathrm{R} \\
\mathrm{R} & \mathrm{R} \\
\mathrm{C} & \mathrm{R} \\
\mathrm{R} & \\
\mathrm{R} & \\
\mathrm{F} & \mathrm{F} \\
& \mathrm{R} \\
& \mathrm{R}\end{array}$ & $\begin{array}{ll}\text { C } & \text { C } \\
\text { C } & \\
\text { C } & \text { C } \\
\text { A } & \text { F } \\
\text { C } & \text { F } \\
\text { C } & \text { C } \\
\text { A } & \text { R } \\
\text { A } & \text { F } \\
\text { A } & \text { F } \\
\text { A } & \\
\text { A } & \text { F } \\
\text { A } & \text { F } \\
\text { A } & \text { F } \\
\text { A } & \text { C } \\
\text { A } & \text { F } \\
\text { C } & \text { F } \\
\text { F } & \\
\text { A } & \text { F } \\
\end{array}$ & $\begin{array}{ll}\text { C } & \text { F } \\
\text { C } & \\
\text { C } & \\
\text { C } & R \\
\text { F } & \\
\text { C } \\
\text { F } \\
\text { C } \\
\text { C } \\
\text { A } \\
\text { C } \\
\text { F } \\
\text { F } \\
\text { C } & \text { R } \\
\text { C } & \\
\text { A } & \text { R } \\
\text { A } & \\
\text { F } & \\
\text { C } & \\
\end{array}$ & $\begin{array}{llll}\mathrm{F} & \mathrm{C} & \mathrm{C} & 1 \\
& \mathrm{C} & \mathrm{C} \\
& \mathrm{C} & \mathrm{C} \\
\mathrm{C} & \mathrm{C} & \mathrm{C} \\
\mathrm{R} & \mathrm{C} & \mathrm{F} \\
\mathrm{R} & \mathrm{A} & \mathrm{C} \\
& & \\
& \mathrm{A} & \mathrm{F} \\
& \mathrm{A} & \mathrm{C} \\
& \mathrm{A} & \mathrm{C} \\
& \mathrm{A} & \mathrm{C} \\
& \mathrm{C} & \mathrm{F} \\
\mathrm{A} & \mathrm{A} & \mathrm{F} \\
\mathrm{R} & \mathrm{A} & \mathrm{C} \\
& \mathrm{C} & \mathrm{C} \\
\mathrm{A} & \mathrm{C} \\
\mathrm{F} & \mathrm{C} & \mathrm{A} \\
& & \mathrm{F} \\
& \mathrm{A} & \mathrm{A}\end{array}$ & \\
\hline PT1a & $\begin{array}{l}6 \mathrm{H}-5,88-90 \\
6 \mathrm{H}-6,121-123 \\
6 \mathrm{H}-\mathrm{CC}, 0-2 \\
7 \mathrm{H}-2,51-53 \\
7 \mathrm{H}-7,30-32 \\
7 \mathrm{H}-\mathrm{CC}, 0-2 \\
8 \mathrm{H}-1,140-142 \\
8 \mathrm{H}-4,70-72 \\
8 \mathrm{H}-\mathrm{CC}, 0-2 \\
9 \mathrm{H}-1,49-51 \\
9 \mathrm{H}-2,28-30 \\
9 \mathrm{H}-2,57-59 \\
9 \mathrm{H}-3,53-55 \\
9 \mathrm{H}-4,135-137 \\
9 \mathrm{H}-6,109-111 \\
9 \mathrm{H}-7,69-70 \\
9 \mathrm{H}-\mathrm{CC}, 0-2 \\
10 \mathrm{H}-1,26-29 \\
10 \mathrm{H}-1,29-32 \\
10 \mathrm{H}-1,66-69 \\
11 \mathrm{X}-1,0-2\end{array}$ & $\begin{array}{l}45.9 \\
47.7 \\
48.22 \\
50.5 \\
57.79 \\
58.05 \\
59.4 \\
63.2 \\
67.63 \\
68 \\
69.3 \\
69.6 \\
71 \\
73.4 \\
76.1 \\
77.2 \\
77.39 \\
77.25 \\
77.27 \\
77.65 \\
79.2\end{array}$ & $\begin{array}{l}45.92 \\
47.72 \\
48.24 \\
50.52 \\
57.81 \\
58.07 \\
50.42 \\
63.22 \\
67.65 \\
68.02 \\
69.32 \\
69.62 \\
71.02 \\
73.42 \\
76.12 \\
77.22 \\
77.41 \\
77.27 \\
77.3 \\
77.67 \\
79.22\end{array}$ & $\begin{array}{l}\text { Pelagic ooze } \\
\text { Pelagic ooze } \\
\text { Pelagic ooze } \\
\text { Pelagic ooze } \\
\text { Pelagic ooze } \\
\text { Black beach sand } \\
\text { Pelagic ooze } \\
\text { Pelagic ooze } \\
\text { Pelagic ooze } \\
\text { Pelagic ooze } \\
\text { Pelagic ooze } \\
\text { Pelagic ooze } \\
\text { Pelagic ooze } \\
\text { Pelagic ooze } \\
\text { Pelagic ooze } \\
\text { Pelagic ooze } \\
\text { Pelagic ooze } \\
\text { Pelagic ooze } \\
\text { Pelagic ooze } \\
\text { Brown clay } \\
\text { Pelagic ooze }\end{array}$ & $\begin{array}{l}\mathrm{F} \\
\mathrm{A} \\
\mathrm{A} \\
\mathrm{F} \\
\mathrm{A} \\
\mathrm{A} \\
\mathrm{C} \\
\mathrm{A}\end{array}$ & $\begin{array}{l}\mathrm{M} \\
\mathrm{M} \\
\mathrm{P} \\
\mathrm{M} \\
\mathrm{M} \\
\mathrm{M} \\
\mathrm{M} \\
\mathrm{M} \\
\mathrm{M} \\
\mathrm{M} \\
\mathrm{M} \\
\mathrm{M} \\
\mathrm{M} \\
\mathrm{M} \\
\mathrm{M} \\
\mathrm{M} \\
\mathrm{M} \\
\mathrm{M} \\
\mathrm{G} \\
\mathrm{G} \\
\mathrm{G}\end{array}$ & $\begin{array}{l}\text { C } \\
\text { F } \\
\text { F } \\
\text { F } \\
\\
\text { A } \\
\text { C } \\
\\
\text { R } \\
\text { F } \\
\text { F } \\
\text { C } \\
\text { F } \\
\text { C } \\
\text { C } \\
\text { F } \\
\text { F }\end{array}$ & $\begin{array}{ll}\text { C } & \text { C } \\
\text { F } & \text { C } \\
\text { F } & \text { R } \\
\text { C } & \text { F } \\
\text { R } & \text { C } \\
\text { R } & \\
\text { C } & \text { F } \\
\text { R } & \text { C } \\
\text { R } & \text { F } \\
\text { R } & \\
\text { F } & \text { F } \\
\text { F } & \\
\text { F } & \text { R } \\
\text { F } & \text { R } \\
\text { R } & \\
\text { R } & \text { F } \\
\text { F } & \text { F } \\
\text { C } & \text { C } \\
\text { R } & \text { C } \\
\text { R } & \text { C } \\
\text { R } & \text { F }\end{array}$ & 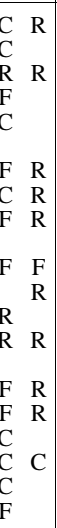 & $\begin{array}{l}\mathrm{R} \\
\mathrm{F} \\
\mathrm{F} \\
\mathrm{C} \\
\mathrm{R}\end{array}$ & $\begin{array}{ll}\mathrm{C} & A \\
\mathrm{~F} & \mathrm{C} \\
\mathrm{F} & \mathrm{F} \\
\mathrm{F} & A \\
\mathrm{C} & \mathrm{C} \\
& \\
\mathrm{F} & \mathrm{C} \\
\mathrm{F} & \mathrm{C} \\
\mathrm{C} & \mathrm{C}\end{array}$ & $\begin{array}{l}\text { A } \\
\text { C } \\
\text { R } \\
\text { A } \\
\text { C }\end{array}$ & $\begin{array}{l}\mathrm{C} \\
\mathrm{C} \\
\mathrm{F} \\
\mathrm{C} \\
\mathrm{C} \\
\mathrm{F} \\
\mathrm{C} \\
\mathrm{C} \\
\mathrm{C}\end{array}$ & 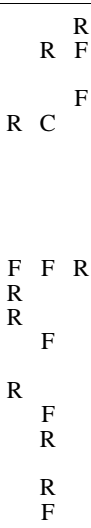 & $\begin{array}{c}\mathrm{R} \\
\mathrm{R} \\
\mathrm{R} \\
\mathrm{R} \\
\mathrm{R}\end{array}$ & $\begin{array}{l}\mathrm{C} \\
\mathrm{F}\end{array}$ & $\begin{array}{l}\mathrm{R} \\
\mathrm{F} \\
\mathrm{R} \\
\mathrm{C} \\
\mathrm{F} \\
\\
\mathrm{F} \\
\mathrm{C}\end{array}$ & $\begin{array}{l}\mathrm{R} \\
\mathrm{R} \\
\mathrm{R}\end{array}$ & $\begin{array}{l}\mathrm{R} \\
\mathrm{R}\end{array}$ & $\begin{array}{lll}\mathrm{A} & \mathrm{R} & \mathrm{F} \\
\mathrm{A} & \mathrm{F} & \mathrm{R} \\
\mathrm{F} & \mathrm{R} & \mathrm{R} \\
\mathrm{A} & \mathrm{R} & \mathrm{F} \\
\mathrm{C} & \mathrm{F} & \mathrm{F} \\
\mathrm{F} & & \\
\mathrm{A} & \mathrm{R} & \mathrm{F} \\
\mathrm{C} & \mathrm{F} & \mathrm{F} \\
\mathrm{A} & \mathrm{F} & \mathrm{F} \\
\mathrm{C} & & \\
\mathrm{C} & \mathrm{R} & \mathrm{R} \\
\mathrm{A} & \mathrm{R} & \mathrm{R} \\
\mathrm{A} & \mathrm{R} & \mathrm{R} \\
\mathrm{A} & \mathrm{R} & \mathrm{R}\end{array}$ & $\begin{array}{l}\text { A } \\
\text { C } \\
\text { F } \\
\text { C } \\
\text { C } \\
\text { F } \\
\text { F } \\
\text { C } \\
\text { C } \\
\\
\text { F } \\
\text { F } \\
\text { C } \\
\text { F }\end{array}$ & 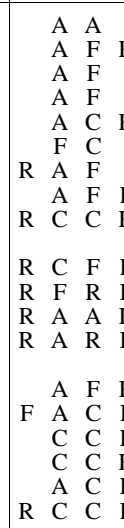 & $\begin{array}{l}\mathrm{F} \\
\mathrm{R} \\
\mathrm{F}\end{array}$ \\
\hline
\end{tabular}

Notes: $*$ indicate reworked specimens. Specimen abundances and grade of preservation appear as letters $($ Shipboard Scientific Party, 1995a, p. 32). A $=$ abundant, $\mathrm{G}=$ good, $\mathrm{F}=$ few, $\mathrm{C}=$ common, $\mathrm{R}=$ rare, $\mathrm{M}=$ moderate, and $\mathrm{P}=$ poor.

tae margaritae to Globorotalia margaritae evoluta Cita is observed at both sites within Zone PL2, the same zone as described by Cita (1973) and Krasheninnikov and Pflaumann (1978). Dextrally coiled specimens of Globorotalia aff. G. hirsuta (illustrated in Iaccarino and Salvatorini, 1979) also occur within upper PL2. The forms are close to G. margaritae evoluta, which, however, shows a consistently sinistral coiling. The two morphologically similar species $G$. margaritae (Globorotalia hirsuta praehirsuta of Blow, 1969) and G. hirsuta have been often confused, and the reports of rare and sporadic occurrences of G. hirsuta within the Pliocene and early Pleistocene are, according to many authors (see also Blow, 1969; Bolli and Saunders, 1985), taxonomic errors. However, we suspect an evolutionary trend between the two species as already pointed out by Blow (1969). The lowest occurrence of G. miocenica, which is rare and sporadic in occurrence at the base of its range, is recorded within Zone PL2 in Samples 157-953C-9R-CC, 0-2 cm (258.9 mbsf), and 157-954B-13R-2, $48-50 \mathrm{~cm}$ (198.5 mbsf). Pulleniatina sp. and Globorotalia plesiotumida Blow and Banner were not observed in Pliocene sections.

The base of Zone PL1 cannot be defined here following Berggren (1977) and Berggren et al. (1995b), because G. dehiscens is absent from the area during the latest Miocene, and Globorotalia tumida is rare and sporadic at Site 953 and absent from Site 954. Globigerinoides conglobatus Brady is also rare and sporadic within lower PL1 at both sites. It first appears in Samples 157-953C-14R-2, 41-43 cm (304.3 mbsf), and 157-954B-20R-1, 81-83 cm (264.5 mbsf). Dextral Neogloboquadrina acostaensis are commonly recorded within PL1. Specimens transitional to G. margaritae margaritae (without keel and left coiling) are assigned to Globorotalia margaritae primitiva Cita. Zone PL1 also includes dextral menardine globorotalids, and few specimens with convex spiral sides identified as Globorotalia pseudomiocenica Bolli and Bermudez. G. crassaformis does not occur within the zone.

\section{The Miocene/Pliocene Boundary}

A set of biostratigraphic criteria has been developed for recognizing the position of the Miocene/Pliocene boundary (Berggren and Van Couvering, 1974; Ryan et al., 1974; Cita, 1975). These include the last appearances of G. dehiscens and G. plesiotumida, and the first appearances of G. margaritae, Globorotalia cibaoensis Bermudez, 
G. tumida, and G. conglobatus (Berggren and Amdurer, 1972; Berggren, 1973, 1977; Berggren et al., 1985; Berggren et al., 1995a, 1995b; Saito et al., 1975; Thunell, 1981).

Many marker species, such as G. tumida, G. plesiotumida, and $G$. conglobatus, are rare and sporadic in occurrence at Sites 953 and 954. The highest occurrence of $G$. dehiscens is recorded at both sites within top Chron C5n (Schmincke, Weaver, Firth, et al., 1995, p. 350). The species has a diachronous last appearance datum (Kennett and Srinivasan, 1975; Hodell and Kennett, 1986) and is rare to absent at the end of its range in the region (see also Cita and Vismara-Schilling, 1980; Salvatorini and Cita, 1979; Weaver, 1987; Weaver and Clement, 1986, 1987; Weaver and Raymo, 1989).

We tentatively used the highest occurrence of Globorotalia juanai to place the boundary, because the taxon is known only from the late Miocene (Bolli and Saunders, 1985; Chaisson and Leckie, 1993). At both sites, we recorded transitional specimens similar to G. margaritae primitiva, but characterized by dextral coiling and the absence of a definite keel, and assigned them to G. juanai following the concepts of Bermudez and Bolli (1969) and Bolli and Saunders (1985). The taxon shows a very distinct preference for dextral coiling throughout its range (Bermudez and Bolli, 1969), whereas G. margaritae and G. margaritae primitiva have a sinistral preference. Weaver (1987) recorded $G$. juanai within the late Miocene Globorotalia conomiozea Zone at Site 608, but several other authors do not mention the species or consider it a synonym of Globorotalia praemargaritae Catalano and Sprovieri and G. margaritae primitiva (Benson and Rakic-El Bied, 1991; Stainforth et al., 1975). Consequently, the Miocene/Pliocene boundary is placed (Tables 3, 4, back-pocket foldout, this volume; Figs. 1, 2) between Samples 157-953C-15R-3, 15$17 \mathrm{~cm}$ (315.25 mbsf), and 15R-CC, 0-2 cm (315.51 mbsf), within upper Gilbert Chron, and between Samples 157-954B-19R-1, 49-51 cm (254.6 mbsf), and 19R-CC, 0-2 cm (255.4 mbsf), within an interval with poor paleomagnetic record. Rare specimens of $G$. tumida have been recorded to Sample 157-953C-16R-3, 40-42 cm (325 mbsf), within the reversed early Gilbert (Berggren et al., 1985; Berggren et al., 1995a, 1995b; Hodell and Kennett, 1986; Schmincke, Weaver, Firth, et al., 1995). The boundary at Site 953 could be moved to the latter sample based on Berggren et al. (1995b). Close to the boundary we found the change in coiling direction of $N$. acostaensis from left to right (Berggren et al., 1985; Salvatorini and Cita, 1979; Stainforth et al., 1975; Zachariasse, 1975) between Samples 157-953C-17R-1, 56-58 cm (331.66 mbsf), and 19R-1, 7-9 cm (350.27 mbsf), within Chron C3An (B. Herr and M. Fuller, pers. comm., 1996) and Samples 157-954B-19R-1, 49-51 cm (254.6 mbsf), and 20R-1, 81-83 cm (265 mbsf), within an interval with no paleomagnetic record (Shipboard Scientific Party, 1995b).

\section{The Miocene}

The sequence was subdivided following Berggren et al. (1983). We could not apply the revised Miocene zonation of Berggren et al. (1995b) because of the total absence or sporadic presence of many zonal markers such as the Globorotalia fohsi group, Globorotalia mayeri Cushman and Ellisor, Globorotalia lenguaensis Bolli, G. plesiotumida, and G. tumida. Particularly, Globorotalia lenguaensis is absent from the area during the late Miocene, and we did not assign any sample to Zone M14.

Samples from $157-953 \mathrm{C}-15 \mathrm{R}-\mathrm{CC}, 0-2 \mathrm{~cm}$ (315.5 mbsf), to 20R$1,67-69 \mathrm{~cm}$ (360.47 mbsf), and from 157-954B-19R-CC, 0-2 cm (255.4 mbsf), to $22 \mathrm{R}-4,76-78 \mathrm{~cm}(288.1 \mathrm{mbsf})$, therefore are assigned to Zone M13 (Berggren et al., 1983) because they contain $G$. margaritae primitiva (Figs. 1, 2). However, the basal boundary is tentatively placed because G. margaritae primitiva is rare and sporadic in occurrence, and its FO is difficult to pick. The first regional occurrence of $G$. margaritae is placed with confidence at Site 953, within C3An.1n Subchron (B. Herr and M. Fuller, pers. comm., 1996), and is consistent with previous published ages in the North Atlantic region (Berggren et al., 1985; Weaver and Clement, 1986;
1987). At Site 954, the event lies in an interval interrupted by several slumps. The lowest appearance of $G$. margaritae is known to be diachronous, and ranges from Chron C3An to basal Chron C3r (Weaver and Clement, 1986, 1987; Hodell and Kennett, 1986; Weaver and Bergsten, 1991).

The basal boundary of Zone M12, marked by the FO of G. conomiozea, occurs in Samples 157-953C-21R-2, 100-103 cm (372 mbsf), and 157-954B-24R-2, 52-54 cm (304 mbsf), at the bottom of Chron C3Bn, as expected (Berggren et al., 1995b). However, we question the reliability of the event at both sites because it lies close to intervals of repeated slumps. The species was consistently recorded in the Bou Regreg section near Rabat (Bossio et al., 1976; Wernli, 1977), whereas it was absent in the Cape Bojador cores (Deep Sea Drilling Project [DSDP] Site 397, Salvatorini and Cita, 1979; Mazzei et al., 1979). Zone M12 contains sinistral $N$. acostaensis, and both dextral and sinistral menardine globorotalids.

The base of Zone M11 is defined by the FO of N. acostaensis, and is placed in Samples 157-953C-33R-4, 59-62 cm (490 mbsf), and 157-954B-31R-6, 90-92 cm (377.5 mbsf). Zone M11 is represented by more solution resistant species such as $N$. acostaensis, G. nepenthes, S. seminulina, Neogloboquadrina sp., dominantly sinistral menardine globorotalids, and rare Globorotalia tumida plesiotumida. Proximal to the base of Zone M11, we found the highest stratigraphic occurrence of $G$. dehiscens in Samples 157-953C-33R-2, 104-106 $\mathrm{cm}$ (487.44 mbsf), and 157-954B-32R-7, 88-90 cm (388.36 mbsf). The event falls within an interval of moderate to poor preservation and seems to be close to the FO of $N$. acostaensis (above it at Site 953 and below at Site 954) within upper Chron C5n (Figs. 1, 2). At Site 953, samples between 157-953C-34R-2, 103-105 cm (497 mbsf), and 38R-5, 84-86 cm, bear G. nepenthes without $N$. acostaensis and are assigned to undifferentiated Zone M9/M10, because Globorotalia paralenguaensis is absent in our samples (Table 3, back-pocket foldout, this volume). Below $539 \mathrm{mbsf}$ (Site 953) and $377.5 \mathrm{mbsf}$ (Site 954), any precise zonal assignment is difficult because of poor preservation.

\section{DISCUSSION Diachronous Datum Levels}

The estimated ages of most biostratigraphic events at Site 953, calculated from age/depth curves based on paleomagnetic data (Fig. 3; Table 5) closely match recently published events within the error inhere in such a model (Berggren et al., 1995a, 1995b). Several events however, are diachronous and merit discussion.

The FO of G. truncatulinoides is widely recognized as a diachronous event (Dowsett, 1988, 1989; Hills and Thierstein, 1989). The first occurrence of the taxon generally occurs near the base of the Olduvai subchron (Hays et al., 1969; Keigwin, 1982; Berggren et al., 1985, Chapman et al., 1996), except in the South Pacific Ocean, where it first occurs close to the Gauss/Matuyama boundary (Kennett, 1973; Dowsett, 1988). Dowsett $(1988,1989)$ suggests that $G$. truncatulinoides evolved in the south Pacific Ocean and then migrated to the South Atlantic Ocean, and subsequently to the tropical and North Atlantic Ocean. The late first occurrence of $G$. truncatulinoides at $\sim 2$ m.y. is confirmed by Weaver (1987) and Chapman et al., (1996) in the North Atlantic Ocean (Sites 606 and 659) and by Weaver and Raymo (1989) in the equatorial Atlantic Ocean. At higher latitude North Atlantic Site 611, Weaver and Clement (1987) report the age of $1.35 \mathrm{Ma}$. Therefore, we question whether the repeated occurrences below the Olduvai Subchron at Sites 953 and 954 could suggest earlier periodic invasions of $G$. truncatulinoides into the Atlantic Ocean, just after its evolution in the Pacific Ocean.

The LO of G. dehiscens at Sites 953 and 954 is recorded within Chron C5n.1n ( 9.740-9.880 m.y.) and clearly predates previous published ages (Table 5). The event is within early Gilbert reversed interval ( 5.8 m.y.) according to Berggren et al., (1995a, 1995b), and ranges from Chron $\mathrm{C} 3 \mathrm{Bn}(\sim 6.8$ m.y.) in subtropical regions to Chron 


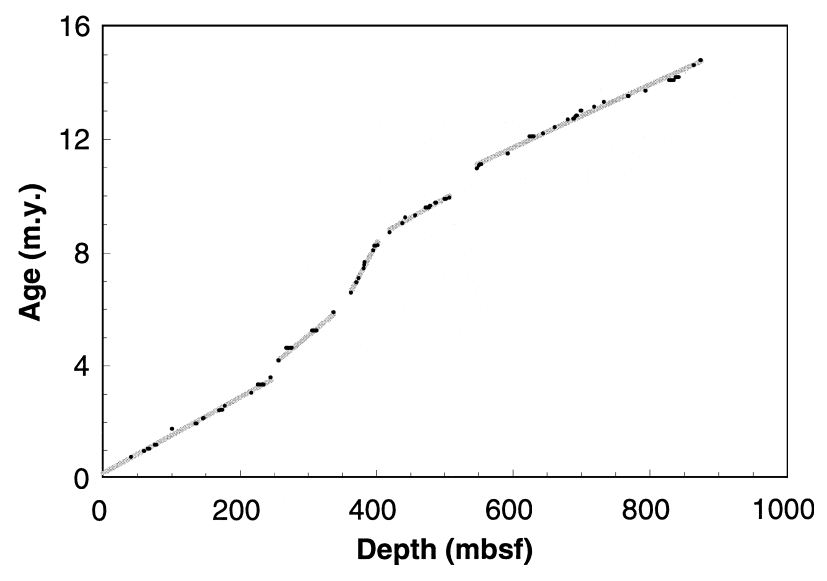

Figure 3. Age model used to estimate the ages of foraminifer first and last appearances at Site 953. The model uses polarity events (B. Herr and M. Fuller, pers. comm., 1996) plotted using the time scale reported in Berggren et al. (1995a, 1995b). Regression lines are lightly sketched through the polarity events. The plot suggests that it is reasonable to assume constant average sedimentation rates during five discrete intervals.

Table 5. Estimated ages of planktonic foraminifer datums at Site 953 compared to the published ages from Berggren et al. (1995a, 1995b).

\begin{tabular}{|c|c|c|c|c|}
\hline Datum events & $\begin{array}{l}\text { Depth } \\
(\mathrm{mbsf})\end{array}$ & $\begin{array}{l}\text { Age } \\
\text { (m.y.) }\end{array}$ & $\begin{array}{c}\text { Est age } \\
\text { (m.y.) }\end{array}$ & $\begin{array}{l}\text { Difference } \\
\quad(\mathrm{m} . \mathrm{y} .)\end{array}$ \\
\hline \multirow[t]{2}{*}{ FO Gg. calida calida } & 0 & 0.22 & 0.2 & 0.02 \\
\hline & 1.3 & 0.22 & 0.22 & 0 \\
\hline \multirow[t]{2}{*}{ FO Gr. hirsuta tropical form } & 28.96 & 0.45 & 0.59 & -0.14 \\
\hline & 33.48 & 0.45 & 0.65 & -0.2 \\
\hline \multirow[t]{2}{*}{ LO Gr. tosaensis } & 36.1 & 0.65 & 0.69 & -0.04 \\
\hline & 36.21 & 0.65 & 0.69 & -0.04 \\
\hline \multirow[t]{2}{*}{ FO pink $G n$. ruber } & 43.71 & 0.76 & 0.79 & -0.03 \\
\hline & 44.35 & 0.76 & 0.8 & -0.04 \\
\hline \multirow[t]{2}{*}{ LO Gn. obliquus extremus } & 125.94 & 1.77 & 1.89 & -0.12 \\
\hline & 127.12 & 1.77 & 1.9 & -0.13 \\
\hline \multirow[t]{2}{*}{ FCO Gr. truncatulinoides } & 140.56 & 2 & 2.08 & -0.08 \\
\hline & 140.95 & 2 & 2.09 & -0.09 \\
\hline \multirow[t]{2}{*}{ FO Gr. inflata } & 141.71 & 2.09 & 2.1 & -0.01 \\
\hline & 144.76 & 2.09 & 2.14 & -0.05 \\
\hline \multirow[t]{2}{*}{ LO Gr. exilis } & 151.65 & 2.15 & 2.23 & -0.08 \\
\hline & 154.49 & 2.15 & 2.27 & -0.12 \\
\hline \multirow[t]{2}{*}{ Reapp. of Pulleniatina } & 154.49 & 2.3 & 2.27 & 0.03 \\
\hline & 154.71 & 2.3 & 2.27 & 0.03 \\
\hline \multirow[t]{2}{*}{ LO Gr. miocenica } & 154.71 & 2.3 & 2.27 & 0.03 \\
\hline & 157.79 & 2.3 & 2.31 & -0.01 \\
\hline \multirow[t]{2}{*}{ LO Gr. puncticulata } & 157.79 & 2.41 & 2.31 & 0.1 \\
\hline & 159.61 & 2.41 & 2.34 & 0.07 \\
\hline \multirow[t]{2}{*}{ LO Gr: multicamerata } & 200.25 & 3.09 & 2.88 & 0.21 \\
\hline & 206.47 & 3.09 & 2.97 & 0.12 \\
\hline \multirow[t]{2}{*}{ LO De. altispira } & 206.47 & 3.09 & 2.97 & 0.12 \\
\hline & 207.41 & 3.09 & 2.98 & 0.11 \\
\hline \multirow[t]{2}{*}{ LO Ss. seminulina } & 207.96 & 3.12 & 2.99 & 0.13 \\
\hline & 216.28 & 3.12 & 3.1 & 0.02 \\
\hline \multirow[t]{2}{*}{ LO Gr: margaritae } & 236.24 & 3.58 & 3.36 & 0.22 \\
\hline & 245.1 & 3.58 & 3.48 & 0.1 \\
\hline \multirow[t]{2}{*}{ FO Gr. puncticulata } & 267.8 & 4.5 & 4.41 & 0.09 \\
\hline & 274.61 & 4.5 & 4.55 & -0.05 \\
\hline \multirow[t]{2}{*}{ LO Gg. nepenthes } & 267.8 & 4.2 & 4.41 & -0.21 \\
\hline & 274.61 & 4.2 & 4.55 & -0.35 \\
\hline \multirow[t]{2}{*}{ LO Gr. juanai } & 315.25 & 5.4 & 5.35 & 0.05 \\
\hline & 315.51 & 5.4 & 5.36 & 0.04 \\
\hline \multirow[t]{2}{*}{ FO Gr. tumida } & 325 & 5.6 & 5.55 & 0.05 \\
\hline & 325.57 & 5.6 & 5.56 & 0.04 \\
\hline \multirow[t]{2}{*}{ FO Gr. margaritae } & 337.59 & 6 & 5.79 & 0.21 \\
\hline & 338.76 & 6 & 5.82 & 0.18 \\
\hline \multirow[t]{2}{*}{ FO Gr. conomiozea } & 372.02 & 7.12 & 7.05 & 0.07 \\
\hline & 373.91 & 7.12 & 7.14 & -0.02 \\
\hline \multirow[t]{2}{*}{ LO Gq. dehiscens } & 485.5 & 5.8 & 9.7 & -3.9 \\
\hline & 487.44 & 5.8 & 9.73 & -3.93 \\
\hline FO $N q$. acostaensis & 489.99 & 10.9 & 9.76 & 1.14 \\
\hline & 497.03 & 10.9 & 9.86 & 1.04 \\
\hline FO Gg. nepenthes & 539.47 & 11.8 & 11.01 & 0.79 \\
\hline & 543.77 & 11.8 & 11.06 & 0.74 \\
\hline
\end{tabular}

Notes: $\mathrm{FO}=$ first occurrence, $\mathrm{LO}=$ last occurrence, and $\mathrm{FCO}=$ first common occurrence .
C3r (early Gilbert, 5.5 m.y.) in the tropics, according to Hodell and Kennett (1986). We observe that the LO of G. dehiscens is a diachronous event from the north to the south Atlantic Ocean. The taxon is virtually absent in the upper Miocene of the Legs 37 and 94 sites near the Azores Islands (Miles, 1977; Weaver and Clement, 1987). At Site 397, (Cape Bojador, North Atlantic, Salvatorini and Cita, 1979), it ranges to Blow's Zone N16 and is very sporadic in the latest Miocene. The estimated ages of the $\mathrm{LO}$ of $G$. dehiscens are progressively younger from Site 659 (8.20-10.50 m.y.) near Cape Verde Island to Sites 661, 664, and 667 near the Sierra Leone Rise (Weaver and Raymo, 1989). The ages in the latter three sites approximate more closely the published ages given in Berggren et al. (1985, 1995a, $1995 \mathrm{~b}$ ) than the ones in northern areas do. Consequently, we think that the cool Canary Current, which widely affected the area off northwest Africa (Sarnthein et al., 1982), strongly influenced the stratigraphic range of G. dehiscens at Sites 953 and 954 as well as in northern Atlantic sites (see also Weaver and Raymo, 1989). The LO of $G$. nepenthes at Site 953 (close to the bottom of Nunivak subchron) is older than previous published ages (Berggren et al., 1985; 1995a) and, seems also to be affected by the cool Canary Current.

The FO of G. margaritae, which is known to be widely diachronous, is quite close to the reported ages from other north Atlantic sites (Weaver and Clement, 1986, 1987).

Other datum levels are slightly different from the published events in Berggren et al., (1995a, 1995b). The first occurrences of $N$. acostaensis and G. nepenthes appear at our Site 953 higher than in other regions. Both events fall within an interval of moderate to poor preservation and are not reliable. Additionally, the stratigraphic position of the FO of N. acostaensis is different from Site 953 to Site 954. It lies below the LO of G. dehiscens at Site 953 and above it at Site 954.

\section{Preservation}

At both sites, preservation follows a similar trend, which is generally good to moderate in the Pleistocene and Pliocene sediments, and decreases markedly in the upper and middle Miocene sections. These findings are consistent with those previously observed in nearby areas (DSDP Leg 94, Weaver, 1987; ODP Leg 108, Weaver and Raymo, 1989; DSDP Leg 41, Krasheninnikov and Pflaumann, 1978; DSDP Site 397, Salvatorini and Cita, 1979; DSDP Site 398, Iaccarino and Salvatorini, 1979) and must represent a regional change in the depth of the CCD. In fact, the calcite compensation depth has fluctuated throughout the Cenozoic in response to changing oceanographic conditions, and its shoaling during the late and middle Miocene is recognized as a global event in the Atlantic, Pacific, and Indian Oceans (Heath, 1969; Berger and Von Rad, 1972; Berger and Winterer, 1974; Van Andel and Moore, 1974; Van Andel, 1975; Van Andel et al., 1975; Ramsay, 1977; Thunell, 1981). Ryan et al. (1974) suggested that the CCD rose dramatically in the late Miocene to compensate for the large amount of carbonate deposited in the Messinian evaporites within the Mediterranean. Its shoaling could be also the result of increased production of Antarctic cold bottom waters triggered by Antarctic glaciations (Van Andel et al., 1975) or a response to the global transgression that occurred during the middle Miocene (Van Andel, 1975).

Specifically, the depth of the CCD in the North Atlantic off northwest Africa (Leg 14 Sites) was $\sim 5000 \mathrm{~m}$ during the Pleistocene and Pliocene and much shallower, $3500-4000 \mathrm{~m}$ during the Miocene (Berger and Von Rad, 1972). Previous downcore variations in percentage of calcium carbonate from North Atlantic DSDP sites show that during the late Miocene, Site 364 (Angola margin, $2448 \mathrm{~m}$ water depth) apparently laid within the lysocline (10\% to $30 \% \mathrm{CaCO}_{3}$ content), whereas deeper sites (Sierra Leone Rise and Cape Verde Basin, respectively, 4588 and $4148 \mathrm{~m}$ water depth) fell to zero carbonate, and they were clearly deeper than the top of the CCD (Thunell, 1981). At Sites 953 and 954 (located, respectively, at 3578 and $3485 \mathrm{~m}$ ) dur- 
ing the late and middle Miocene, the carbonate content did not fall to zero. Consequently, we can assume that both sites fell within the lysocline but remained consistently above the CCD, which was at least as shallow as $4000 \mathrm{~m}$, as suggested by Thunell (1981).

\section{CONCLUSIONS}

The planktonic foraminiferal fauna at Sites 953 and 954 indicates water masses similar to North Atlantic areas similarly affected by the cool North Atlantic and Canary currents. Estimated ages of datum events, calibrated to an excellent paleomagnetic stratigraphy for Site 953, tie well with previous data from North Atlantic sites within the error of the age model. A unique and still puzzling record is the lowest regional occurrence of $G$. truncatulinoides, which appears at both sites much earlier than in other neighboring areas, within Zone PL5, and requires confirmation at other sites.

The redefined Pliocene/Pleistocene zonation of Berggren et al. (1995b) can be successfully applied in the Canary Island region, but we prefer the Miocene zonation of Berggren et al. (1983) for the poorly preserved Miocene sections, because of the absence of many zonal markers.

Preservation of planktonic foraminifers and calcium carbonate content in the Canary Island region sites follows a regional trend linked to a definite shoaling of the CCD during late to middle Miocene times.

\section{ACKNOWLEDGMENTS}

We gratefully acknowledge the data, results, and many fruitful discussions shared with our Leg 157 colleagues. The research was supported in part by a grant from JOI/USSSP to Brunner and in part by a CNR grant to Maniscalco during her stay at the Istituto di Geologia Marina, CNR Bologna (Italy). We thank Ms. Susan Moffett for preparation of some of the samples and maintenance of the sample database. (Institute of Marine Sciences Contribution Number 0183). We thank Drs. Maria Bianca Cita and Mark Chapman for reviewing the manuscript.

\section{REFERENCES}

Benson, R.H., and Rakic-El Bied, K., 1991. The Messinian parastratotype at Cuevas de Almanzora, Vera Basin, SE Spain: refutation of the deep-basin shallow water hypothesis? Micropaleontology, 37:265-313.

Berger, W.H., and von Rad, U., 1972. Cretaceous and Cenozoic sediments from the Atlantic Ocean. In Hayes, D.E., Pimm, A.C., et al., Init. Repts. DSDP, 14: Washington (U.S. Govt. Printing Office), 787-954.

Berger, W.H., and Winterer, E.L., 1974. Plate stratigraphy and the fluctuating carbonate line. In Hsü, K.J., and Jenkyns, H.C. (Eds.), Pelagic Sediments on Land and Under the Sea. Spec. Publ. Int. Assoc. Sedimentol., 1:1148.

Berggren, W.A., 1973. The Pliocene time scale: calibration of planktonic foraminiferal and calcareous nannoplankton zones. Nature, 243:391-397.

1977. Late Neogene planktonic foraminiferal biostratigraphy of the Rio Grande Rise (South Atlantic). Mar. Micropaleontol., 2:265-313.

Berggren, W.A., and Amdurer, M., 1972. Late Paleogene (Oligocene) and Neogene planktonic foraminiferal biostratigraphy of the Atlantic Ocean (Lat. $30^{\circ} \mathrm{N}$ to $30^{\circ} \mathrm{S}$ ). Riv. Ital. Paleontol. Stratigr., 79:337-392.

Berggren, W.A., Aubry, M.P., and Hamilton, N., 1983. Neogene magnetostratigraphy of Deep Sea Drilling Project Site 516 (Rio Grande Rise, South Atlantic). In Barker, P.F., Carlson, R.L., Johnson, D.A., et al., Init. Repts. DSDP, 72: Washington (U.S. Govt. Printing Office), 675-713.

Berggren, W.A., Hilgen, F.J., Langereis, C.G., Kent, D.V., Obradovich, J.D., Raffi, I., Raymo, M.E., and Shackleton, N.J., 1995a. Late Neogene chronology: new perspectives in high-resolution stratigraphy. Geol. Soc. Am. Bull., 107:1272-1287.

Berggren, W.A., Kent, D.V., Swisher, C.C., III, and Aubry, M.-P., 1995b. A revised Cenozoic geochronology and chronostratigraphy. In Berggren, W.A., Kent, D.V., Aubry, M.-P., and Hardenbol, J. (Eds.), Geochronol- ogy, Time Scales and Global Stratigraphic Correlation. Spec. Publ.Soc. Econ. Paleontol. Mineral., 54:129-212.

Berggren, W.A., Kent, D.V., and Van Couvering, J.A., 1985. The Neogene, Part 2. Neogene geochronology and chronostratigraphy. In Snelling, N.J. (Ed.), The Chronology of the Geological Record. Geol. Soc. London Mem., 10:211-260.

Berggren, W.A., and van Couvering, J.A., 1974. The Late Neogene: biostratigraphy, geochronology and paleoclimatology of the last 15 million years in marine and continental sequences. Palaeogeogr., Palaeoclimatol,. Palaeoecol., 16:1-216.

Bermudez, P.J., and Bolli, H.M., 1969. Consideraciones sobre los sedimentos del Mioceno medio al Reciente de las costas central y oriental de Venezuela. Bol. Geol., Dir. Geol., Minister. Minas Hidrocarb., 10:137-223.

Blow, W.H., 1969. Late middle Eocene to Recent planktonic foraminiferal biostratigraphy. In Brönnimann, P., and Renz, H.H. (Eds.), Proc. First Int. Conf. Planktonic Microfossils, Geneva, 1967: Leiden (E.J. Brill), 1:199-422.

Bolli, H.M., and Premoli Silva, I., 1973. Oligocene to Recent planktonic foraminifera and stratigraphy of the Leg 15 sites in the Caribbean Sea. In Edgar, N.T., Saunders, J.B., et al., Init. Repts. DSDP, 15: Washington (U.S. Govt. Printing Office), 475-497.

Bolli, H.M., and Saunders, J.B., 1985. Oligocene to Holocene low latitude planktic foraminifera. In Bolli, H.M., Saunders, J.B., and Perch-Nielsen, K. (Eds.), Plankton Stratigraphy: Cambridge (Cambridge Univ. Press), $155-262$.

Bossio, A., Rakic-El Bied, K., Giannelli, L., Mazzei, R., Russo, R., and Salvatorini, G., 1976. Correlation de quelques sections stratigraphiques du Mio-Pliocene de la zone atlantique du Maroc avec le stratotypes du Bassin Mediterraneen sur la base des foraminiferes plantoniques, nannoplancton calcaire et ostracodes. Atti Soc. Tosc. Sc. Nat. Mem., 83:121137.

Chaisson, W.P., and Leckie, R.M., 1993. High-resolution Neogene planktonic foraminifer biostratigraphy of Site 806, Ontong Java Plateau (western equatorial Pacific). In Berger, W.H., Kroenke, L.W., Mayer, L.A., et al., Proc. ODP, Sci. Results, 130: College Station, TX (Ocean Drilling Program), 137-178.

Chapman, M.R., Funnell, B.M., and Weaver, P.P.E., 1996. High resolution Pliocene planktonic foraminiferal biozonation of the tropical North Atlantic. In Moguilevsky, A., and Whatley, R. (Eds.), Microfossils and Oceanic Environments: Aberystwyth (Univ. of Wales Press), 307-316.

Cita, M.B., 1973. Pliocene biostratigraphy and chronostratigraphy. In Ryan, W.B.F., Hsü, K.J., et al., Init. Repts. DSDP, 13 (Pt. 2): Washington (U.S. Govt. Printing Office), 1343-1379.

1975. The Miocene/Pliocene boundary: history and definition. In Saito, T., and Burckle, L.H., (Eds.), Late Neogene Epoch Boundaries. Spec. Publ. Micropaleontol., 1-30.

Cita, M.B., and Vismara-Schilling, A., 1980. Planktonic-foraminifer assemblages across the Mio-Pliocene boundary at Deep Sea Drilling Project Sites 415 and 416, and correlations with other north-Atlantic successions. In Lancelot, Y., Winterer, E.L., et al., Init. Repts. DSDP, 50: Washington (U.S. Govt. Printing Office), 497-505.

Corliss, B.H., 1975. Late Pleistocene paleoclimatology: planktonic foraminiferal analysis of sediment cores from the central North Atlantic. Palaeogeogr., Palaeoclimatol., Palaeoecol., 18:45-61.

Dowsett, H.J., 1988. Diachroneity of Late Neogene microfossils in the southwest Pacific Ocean: application of the graphic correlation method. Paleoceanography, 3:209-222.

, 1989. Application of the graphic correlation method to Pliocene marine sequences. Mar. Micropaleontol., 14:3-32.

Ericson, D.B., and Wollin, G., 1968. Pleistocene climates and chronology in deep-sea sediments. Science, 162:1227-1234.

Hay, W.W., and Beaudry, F.M., 1973. Calcareous nannofossils--Leg 15, Deep Sea Drilling Project. In Edgar, N.T., Saunders, J.B., et al., Init. Repts. DSDP, 15: Washington (U.S. Govt. Printing Office), 625-683.

Hays, J.D., Saito, T., Opdyke, N.D., and Burckle, L.H., 1969. Pliocene-Pleistocene sediments of the equatorial Pacific: their paleomagnetic, biostratigraphic, and climatic record. Geol. Soc. Am. Bull., 80:1481-1513.

Heath, G.R., 1969. Carbonate sedimentation in the abyssal equatorial Pacific during the past 50 million years. Geol. Soc. Am. Bull., 80:689-694.

Hills, S.J., and Thierstein, H.R., 1989. Plio-Pleistocene calcareous plankton biochronology. Mar. Micropaleontol., 14:67-96.

Hodell, D.A., and Kennett, J.P., 1986. Late Miocene-early Pliocene stratigraphy and paleoceanography of the South Atlantic and southwest Pacific Oceans: a synthesis. Paleoceanography, 1:285-311. 
Iaccarino, S., and Salvatorini, G., 1979. Planktonic foraminiferal biostratigraphy of Neogene and Quaternary of Site 398 of DSDP Leg 47B. In Sibuet, J.-C., Ryan, W.B.F., et al., Init. Repts. DSDP, 47 (Pt. 2): Washington (U.S. Govt. Printing Office), 255-285.

Keigwin, L.D., Jr., 1982. Neogene planktonic foraminifers from Deep Sea Drilling Project Sites 502 and 503. In Prell, W.L., Gardner, J.V., et al., Init. Repts. DSDP, 68: Washington (U.S. Govt. Printing Office), 269288.

Kennett, J.P., 1973. Middle and late Cenozoic planktonic foraminiferal biostratigraphy of the Southwest Pacific-DSDP Leg 21. In Burns, R.E., Andrews, J.E., et al., Init. Repts. DSDP, 21: Washington (U.S. Govt. Printing Office), 575-639.

Kennett, J.P., and Srinivasan, M.S., 1975. Stratigraphic occurrences of the Miocene planktonic foraminifera Globoquadrina dehiscens in the early Pliocene sediments of the Indian Ocean. Rev. Esp. Micropaleontol., 7:514.

Krasheninnikov, V.A., and Pflaumann, U., 1978. Zonal stratigraphy and Neogene deposits of the eastern part of the Atlantic Ocean by means of planktonic foraminifers, Leg 41, Deep Sea Drilling Project. In Lancelot, Y., Seibold, E., et al., Init. Repts. DSDP, 41: Washington (U.S. Govt. Printing Office), 613-657.

Mazzei, R., Raffi, I., Rio, D., Hamilton, N., and Cita, M.B., 1979. Calibration of late Neogene calcareous plankton datum planes with the paleomagnetic record of Site 397 and correlation with Moroccan and Mediterranean sections. In von Rad, U., Ryan, W.B.F., et al., Init. Repts. DSDP, 47 (Pt. 1): Washington (U.S. Govt. Printing Office), 375-389.

Miles, G.A., 1977. Planktonic foraminifera from Leg 37 of the Deep Sea Drilling Project. In Aumento, F., Melson, W.G., et al., Init. Repts. DSDP, 37: Washington (U.S. Govt. Printing Office), 929-961.

Parker, F.L., 1962. Planktonic foraminiferal species in Pacific sediments. Micropaleontology, 8:219-254.

1967. Late Tertiary biostratigraphy (planktonic foraminifera) of tropical Indo-Pacific deep-sea cores. Bull. Am. Paleontol., 52:111-208.

Pflaumann, U., and Krasheninnikov, V.A., 1979. Quaternary stratigraphy and planktonic foraminifers of the eastern Atlantic, Deep Sea Drilling Project, Leg 41. In Lancelot, Y., Siebold, E., et al., Init. Repts. DSDP, 41 (Suppl. to Vol. 38, 39, 40, and 41): Washington (U.S. Govt. Printing Office), 883-911.

Pujol, C., and Duprat, J., 1983. Quaternary planktonic foraminifers of the southwestern Atlantic (Rio Grande Rise) Deep Sea Drilling Project Leg 72. In Barker, P.F., Carlson, R.L., Johnson, D.A., et al., Init. Repts. DSDP, 72: Washington (U.S. Govt. Printing Office), 601-615.

Ramsay, A.T.S., 1977. Sedimentological clues to paleoceanography. In Ramsay, A.T.S. (Ed.), Oceanic Micropaleontology (Vol. 2): New York (Academic Press), 1371-1453.

Ryan, W.B.F., Cita, M.B., Rawson, M.D., Burckle, L.H., and Saito, T., 1974. A paleomagnetic assignment of Neogene stage boundaries and the development of isochronous datum planes between the Mediterranean, the Pacific and Indian oceans in order to investigate the response of the world ocean to the Mediterranean "salinity crisis." Riv. Ital. Paleontol., 80:631-688.

Saito, T., Burckle, L.H., and Hays, J.D., 1975. Late Miocene to Pleistocene biostratigraphy of equatorial Pacific sediments. In Saito, T., and Burckle, L.H. (Eds.), Late Neogene Epoch Boundaries. Micropaleontol., Spec. Publ., 1:226-244.

Salvatorini, G., and Cita, M.B., 1979. Miocene foraminiferal biostratigraphy, DSDP Site 397 (Cape Bojador, North Atlantic). In von Rad, U., Ryan, W.B.F., et al., Init. Repts. DSDP, 47 (Pt. 1): Washington (U.S. Govt. Printing Office), 371-373.

Sarnthein, M., Thiede, J., Pflaumann, U., Erlenkeuser, H., Fütterer, D., Koopmann, B., Lange, H., and Seibold, E., 1982. Atmospheric and oce- anic circulation patterns off Northwest Africa during the past 25 million years. In von Rad, U., Hinz, K., Sarnthein, M., Seibold, E. (Eds.), Geology of the Northwest African Continental Margin: Berlin (Springer Verlag), 545-604.

Schmincke, H.-U., Weaver, P.P.E., Firth, J.V., et al., 1995. Proc. ODP, Init. Repts., 157: College Station, TX (Ocean Drilling Program).

Shipboard Scientific Party, 1995a. Explanatory notes. In Schmincke, H.-U., Weaver, P.P.E., Firth, J.V., et al., Proc. ODP, Init. Repts., 157: College Station, TX (Ocean Drilling Program), 27-48.

1995b. Site 954. In Schmincke, H.-U., Weaver, P.P.E., Firth, J.V., et al., Proc. ODP, Init. Repts., 157: College Station, TX (Ocean Drilling Program), 395-431.

Stainforth, R.M., Lamb, J.L., Luterbacher, H., Beard, J.H., and Jeffords, R.M., 1975. Cenozoic planktonic foraminiferal zonation and characteristics of index forms. Univ. Kans. Paleontol. Contrib., Article, 62:1-425.

Sverdrup, H.U., Johnson, M.W., and Fleming, R. (Eds.), 1947. The Oceans: Their Physics, Chemistry and General Biology: Englewood Cliffs, NJ (Prentice-Hall).

Thunell, R.C., 1981. Late Miocene-early Pliocene planktonic foraminiferal biostratigraphy and paleoceanography of low latitude marine sequences. Mar. Micropaleontol., 6:71-90.

van Andel, T.H., 1975. Mesozoic/Cenozoic calcite compensation depth and the global distribution of calcareous sediments. Earth Planet. Sci. Lett., 26:187-194.

van Andel, T.H., Heath, G.R., and Moore, T.C., Jr., 1975. Cenozoic history and paleoceanography of the central equatorial Pacific Ocean: a regional synthesis of Deep Sea Drilling Project data. Mem.-Geol. Soc. Am., 143.

van Andel, T.H., and Moore, T.C., Jr., 1974. Cenozoic calcium carbonate distribution and calcite compensation in the central equatorial Pacific Ocean. Geology, 2:87-92.

Weaver, P.P.E., 1987. Late Miocene to Recent Planktonic foraminifers from the North Atlantic: Deep Sea Drilling Project Leg 94. In Ruddiman, W.F., Kidd, R.B., Thomas E., et al., Init. Repts. DSDP, 94: Washington (U.S. Govt. Printing Office), 703-727.

Weaver, P.P.E., and Bergsten, H., 1991. Assessing the accuracy of fossil datum levels Globorotalia margaritae foraminiferida: a Pliocene test case. J. Micropaleontol., 9:225-231.

Weaver, P.P.E., and Clement, B.M., 1986. Synchroneity of Pliocene planktonic foraminiferal datums in the North Atlantic. Mar. Micropaleontol., 10:295-307.

, 1987. Magnetobiostratigraphy of planktonic foraminiferal datums, DSDP Leg 94, North Atlantic. In Ruddiman, W.F., Kidd, R.B., Thomas, E., et al., Init. Repts. DSDP, 94: Washington (U.S. Govt. Printing Office), 815-829.

Weaver, P.P.E., and Raymo, M.E., 1989. Late Miocene to Holocene planktonic foraminifers from the equatorial Atlantic, Leg 108. In Ruddiman, W., Sarnthein, M., et al., Proc. ODP, Sci. Results, 108: College Station, TX (Ocean Drilling Program), 71-91.

Wernli, R., 1977. Le foraminiferes planctoniques de la limite Mio-Pliocene dans les environ de Rabat (Maroc). Eclogae Geol. Helv., 70:143-191.

Zachariasse, W.J., 1975. Planktonic foraminiferal biostratigraphy of the late Neogene of Crete (Greece). Utrecht Micropaleontol. Bull., 11.

Date of initial receipt: 27 June 1996

Date of initial acceptance: 10 January 1997 Ms 157SR-109 